\title{
Untangling hidden nutrient dynamics: rapid ammonium cycling and single-cell ammonium assimilation in marine plankton communities
}

\author{
Isabell Klawonn ${ }^{1,2}$. Stefano Bonaglia $\mathbb{1}^{1,3} \cdot$ Martin J. Whitehouse $\mathbb{I}^{4} \cdot$ Sten Littmann $^{5} \cdot$ Daniela Tienken $^{5}$. \\ Marcel M. M. Kuypers ${ }^{5} \cdot$ Volker Brüchert ${ }^{3} \cdot$ Helle Ploug $^{1,6}$
}

Received: 11 September 2018 / Revised: 25 February 2019 / Accepted: 27 February 2019 / Published online: 25 March 2019

(c) The Author(s) 2019. This article is published with open access

\begin{abstract}
Ammonium is a central nutrient in aquatic systems. Yet, cell-specific ammonium assimilation among diverse functional plankton is poorly documented in field communities. Combining stable-isotope incubations $\left({ }^{15} \mathrm{~N}\right.$-ammonium, ${ }^{15} \mathrm{~N}_{2}$ and ${ }^{13} \mathrm{C}$ bicarbonate) with secondary-ion mass spectrometry, we quantified bulk ammonium dynamics, $\mathrm{N}_{2}$-fixation and carbon (C) fixation, as well as single-cell ammonium assimilation and $\mathrm{C}$-fixation within plankton communities in nitrogen (N)-depleted surface waters during summer in the Baltic Sea. Ammonium production resulted from regenerated $(\geq 91 \%)$ and new production ( $\mathrm{N}_{2}$-fixation, $\leq 9 \%$ ), supporting primary production by $78-97$ and $2-16 \%$, respectively. Ammonium was produced and consumed at balanced rates, and rapidly recycled within $1 \mathrm{~h}$, as shown previously, facilitating an efficient ammonium transfer within plankton communities. $\mathrm{N}_{2}$-fixing cyanobacteria poorly assimilated ammonium, whereas heterotrophic bacteria and picocyanobacteria accounted for its highest consumption $(\sim 20$ and $\sim 20-40 \%$, respectively). Surprisingly, ammonium assimilation and C-fixation were similarly fast for picocyanobacteria (non- $\mathrm{N}_{2}$-fixing Synechococcus) and large diatoms (Chaetoceros). Yet, the population biomass was high for Synechococcus but low for Chaetoceros. Hence, autotrophic picocyanobacteria and heterotrophic bacteria, with their high single-cell assimilation rates and dominating population biomass, competed for the same nutrient source and drove rapid ammonium dynamics in $\mathrm{N}$ depleted marine waters.
\end{abstract}

Supplementary information The online version of this article (https:// doi.org/10.1038/s41396-019-0386-z) contains supplementary material, which is available to authorised users.

Isabell Klawonn

klawonn@igb-berlin.de

1 Department of Ecology, Environment and Plant Sciences, Stockholm University, 10691 Stockholm, Sweden

2 Department of Experimental Limnology, IGB-Leibniz-Institute of Freshwater Ecology and Inland Fisheries, 12587 Berlin, Germany

3 Department of Geological Sciences, Stockholm University, 10691 Stockholm, Sweden

4 Swedish Museum of Natural History, 11418 Stockholm, Sweden

5 Max Planck Institute for Marine Microbiology, 29357 Bremen, Germany

6 Department of Marine Sciences, University of Gothenburg, 40530 Gothenburg, Sweden

\section{Introduction}

In various aquatic environments, ranging from inland lakes, brackish seas to the global ocean, primary production is fuelled by $\mathrm{N}_{2}$-fixation [1] and regenerated nitrogen $(\mathrm{N})$, including ammonium [2,3]. Only few microorganisms, e.g., filamentous cyanobacteria are able to reduce $\mathrm{N}_{2}$ to ammonium [1]. In contrast, ammonium is highly bioavailable and thus the predominant $\mathrm{N}$-compound assimilated by bacterioplankton and phytoplankton [4, 5]. Its cycling is complex, driven by various sources and sinks in plankton communities. In brief, ammonium is consumed through assimilation and nitrification (oxidation of ammonium to nitrite/ nitrate). In turn, it is regenerated by bacterial remineralisation of organic $\mathrm{N}$, zooplankton grazing, parasitic infections, or cell lysis [6]. New sources include ammonium leakage from diazotrophic cyanobacteria [7-9] which fix $\mathrm{N}$ in excess relative to their cellular $\mathrm{C}: \mathrm{N}$ ratio.

Ammonium assimilation by individual microbes in natural communities is difficult to quantify, mainly due to methodological limitations. In the past, nutrient assimilation 
in mixed plankton communities was best discriminated after water pre-filtration, i.e., size-fractionation. However, sizefractionation poorly separates plankton taxa of similar size or closely associated cells, often causes cell disruption and concurrent ammonium release, and destructs interactions between trophic levels $[10,11]$. More recently, assimilation rates have been analysed by either stable-isotope probing [12] or flow cytometry combined with stable-isotope analyses [13] but both approaches are limited to most abundant taxa and cannot reveal single-cell activities. These methodological limitations can be resolved by secondary-ion mass spectrometry (SIMS) which enables single-cell analyses in mixed field populations after stable-isotope incubations [14]. Nutrient assimilation can thereby be differentiated between individual taxa and even cells while natural microbial interactions and nutrient concentrations remain relatively undisturbed.

Our study was motivated by two uncertainties in aquatic geomicrobiology. First, single-cell ammonium assimilation rates in natural marine plankton communities are poorly explored but crucial to elucidate taxa-specific nutrient preferences, assimilation rates and quantitatively important taxa for ammonium cycling. Second, previous studies have quantified the contribution of diazotrophs to primary production [e.g., ref. [15]] and $\mathrm{N}_{2}$-fixation as a new N-source, which becomes available as ammonium [7-9] or DON [9, 16-18]. Further, the transfer of new $\mathrm{N}$ from $\mathrm{N}_{2}$-fixing microbes to other phytoplankton, bacteria and zooplankton has been studied intensively during recent years in different environments, e.g., in the tropical South Pacific Ocean [19, 20], Gulf of Mexico and Caribbean Sea [17, 21], Southwest Pacific [22] and Baltic Sea [23-26]. However, the quantitative importance of new ammonium from $\mathrm{N}_{2}$-fixation in direct comparison to regenerated ammonium in field communities remains poorly known [but see ref. [27]]. In order to resolve these uncertainties, we studied ammonium cycling in N-depleted surface waters in the Baltic Sea, a semi-enclosed sea which has been monitored for more than 30 years [28]. Singlecell and large-scale observations have suggested that the new $\mathrm{N}$-source from $\mathrm{N}_{2}$-fixation can be equal to or even exceed net $\mathrm{N}_{2}$-fixation [7, 8, 23, 29, 30]. Moreover, $\mathrm{N}$ losses from the photic zone appear to be low and new $\mathrm{N}$ from $\mathrm{N}_{2}$-fixation is effectively transferred into pelagic food webs, explaining the observed increase in the total $\mathrm{N}$ inventory during summer [29, 31]. In the present study, we quantified ammonium processes, as well as $\mathrm{N}_{2}$-fixation and $\mathrm{C}$-fixation in the photic zone using isotopic tracer incubations, mass spectrometry, ammonium analyses and microscopy, and linked our findings on the small-scale to existing meso-scale observations. The data collected foster our quantitative and mechanistic understanding of interlinked plankton growth and N-dynamics in marine waters, in which $\mathrm{N}$-depletion, ammonium-based production and $\mathrm{N}_{2}$-fixation are prevalent.

\section{Materials and methods}

\section{Study area and water sampling}

Surface water (1-3 m) was collected with a water sampler (NM Tech AB, Stockholm, Sweden) at a coastal station in the Baltic Sea (station B1 of the Swedish National Marine Monitoring Program, N 58 48' 18 E $17^{\circ} 37^{\prime}$ 52, depth $40 \mathrm{~m}$ ) in June 2012 and August 2013. Sub-samples were $0.45 \mu \mathrm{m}$-filtered and stored at $-20{ }^{\circ} \mathrm{C}$ for later nutrient analyses on a segmented flow nutrient analyser (ALPKEM O.I. Analytical Flow Solution IV, methods: phosphate \#319528, nitrite + nitrate \#319527, and nitrite \#319527; with reporting limits of 16,21 and $14 \mathrm{nmol} \mathrm{L}^{-1}$, respectively). Ammonium was analysed immediately (see below). Depth profiles of temperature, salinity, oxygen and light were recorded with a CTD (CTM577, Sea \& Sun).

\section{Water incubations}

Water was filled headspace-free into $1 \mathrm{~L}$ Duran ${ }^{\circledR}$ bottles. Three bottles were amended with ${ }^{15} \mathrm{~N}$-ammonium $\left({ }^{15} \mathrm{NH}_{4} \mathrm{Cl}, 98\right.$ atom\% ${ }^{15} \mathrm{~N}, \# 299251$ Aldrich) and ${ }^{13} \mathrm{C}-\mathrm{DIC}$ ( ${ }^{13} \mathrm{C}$-sodium bicarbonate, 98 atom\%, \#372382 Aldrich), another three bottles with ${ }^{15} \mathrm{~N}_{2}$ (98 atom\% ${ }^{15} \mathrm{~N}$, \#364584 Aldrich) and ${ }^{13} \mathrm{C}$-DIC, and one bottle served as control without isotope additions. ${ }^{15} \mathrm{~N}$-ammonium concentrations were $20-30 \mathrm{nM}$, equal to final ${ }^{15} \mathrm{~N}$-label percentages of $5-$ $46 \%$. ${ }^{13} \mathrm{C}$-DIC was added to a final label percentage of $5 \%$ (methods described below). ${ }^{15} \mathrm{~N}$-labelled $\mathrm{N}_{2}$ gas was added as pre-dissolved ${ }^{15} \mathrm{~N}_{2}$ [32], yielding final ${ }^{15} \mathrm{~N}$-label percentages of $1 \%$ in 2012 and $9 \%$ in 2013 . False $\mathrm{N}_{2}$-fixation rates due to ${ }^{15} \mathrm{~N}$-contaminations in the gas bottles [33] could be excluded since the ${ }^{15} \mathrm{~N}_{2}$-amended water was tested negative for ${ }^{15} \mathrm{~N}$-ammonium (analyses described below).

Water was sampled freshly $1 \mathrm{~h}$ before each incubation which took place at $0.5 \mathrm{~m}$ water depth in a mesocosm basin at in situ temperature and ambient light (Fig. S1) for approximately $3 \mathrm{~h}$ at four different times of the day (Table 1). The following sub-samples were taken at two ( $\mathrm{t} 0$ and $\mathrm{t} 3$ ) or three time-points $(\mathrm{t} 0, \mathrm{t} 1, \mathrm{t} 3)$ from the ${ }^{15} \mathrm{~N}_{2^{-}}$ ammonium and ${ }^{15} \mathrm{~N}$-ammonium amended bottles, respectively: (i) ${ }^{15} \mathrm{~N}$-ammonium concentrations, and ${ }^{15} \mathrm{~N}_{2}$-labelling and ${ }^{13}$ C-labelling-Triplicate sub-samples were preserved in $12 \mathrm{~mL}$ Exetainer $^{\circledR}$ vials with $100 \mu \mathrm{L}$ saturated $\mathrm{ZnCl}_{2}$ solution. (ii) Bulk ammonium concentrations $-40 \mathrm{~mL}$ were transferred into acid-washed Falcon tubes plus $10 \mathrm{~mL}$ ortho-phthalaldehyde solution. Ammonium concentrations were determined on a fluorometer (Turner design, TD-700) 
Table 1 Rates of ammonium cycling processes, $\mathrm{N}_{2}$-fixation and $\mathrm{C}$-fixation

\begin{tabular}{|c|c|c|c|c|c|c|c|c|c|c|}
\hline \multirow[t]{2}{*}{ Date } & \multirow[t]{2}{*}{$\begin{array}{l}\text { Incubation } \\
\text { period }\end{array}$} & \multirow{2}{*}{$\begin{array}{l}\text { Bulk } \mathrm{NH}_{4}^{+} \\
\text {concentration } \\
\text { (nM) }\end{array}$} & \multirow{2}{*}{$\begin{array}{l}\text { Gross } \mathrm{NH}_{4}^{+} \\
\text {consumption } \\
\left(\text { nmol } \mathrm{N} \mathrm{h}^{-1} \mathrm{~L}^{-1}\right)\end{array}$} & \multirow{2}{*}{$\begin{array}{l}\text { Gross } \mathrm{NH}_{4}^{+} \\
\text {production } \\
\left(\text { nmol } \mathrm{N} \mathrm{h}^{-1}\right. \\
\left.\mathrm{L}^{-1}\right)\end{array}$} & \multirow{2}{*}{$\begin{array}{l}\text { Net } \mathrm{NH}_{4}{ }^{+} \text {rate } \\
\left(\mathrm{nmol} \mathrm{N} \mathrm{h}^{-1}\right. \\
\left.\mathrm{L}^{-1}\right)\end{array}$} & \multicolumn{2}{|c|}{$\begin{array}{l}\mathrm{NH}_{4}^{+} \text {assimilation } \\
\left(\text { nmol } \mathrm{N} \mathrm{h}^{-1} \mathrm{~L}^{-1}\right)\end{array}$} & \multirow[t]{2}{*}{$\begin{array}{l}\mathrm{NH}_{4}^{+} \\
\text {turnover (h) }\end{array}$} & \multirow{2}{*}{$\begin{array}{l}\mathrm{N}_{2} \text {-fixation } \\
\left(\mathrm{nmol} \mathrm{N} \mathrm{h}^{-1}\right. \\
\left.\mathrm{L}^{-1}\right)\end{array}$} & \multirow{2}{*}{$\begin{array}{l}\text { C-fixation } \\
\left(\text { nmol } \mathrm{C} \mathrm{h}^{-1}\right. \\
\left.\mathrm{L}^{-1}\right)\end{array}$} \\
\hline & & & & & & $\begin{array}{l}\text { Analysed } \\
\text { on } \mathrm{GF} / \mathrm{F}\end{array}$ & $\begin{array}{l}\text { Analysed } \\
\text { by SIMS }\end{array}$ & & & \\
\hline \multicolumn{11}{|c|}{ 28/29-June-2012 } \\
\hline & $07: 30-10: 30$ & $\begin{array}{l}111 \pm 44 \\
(n=3)\end{array}$ & $\begin{array}{l}79 \pm 24 \\
(n=9)\end{array}$ & $\begin{array}{l}79 \pm 24 \\
(n=9)\end{array}$ & 0 & $\begin{array}{l}78 \pm 29 \\
(n=9)\end{array}$ & $50 \pm 34$ & 1.4 & $\begin{array}{l}9 \pm 1 \\
(n=3)\end{array}$ & $\begin{array}{l}167 \pm 55 \\
(n=3)\end{array}$ \\
\hline & $12: 00-15: 00$ & $\begin{array}{l}97 \pm 9 \\
(n=3)\end{array}$ & $\begin{array}{l}65 \pm 11 \\
(n=9)\end{array}$ & $\begin{array}{l}65 \pm 11 \\
(n=9)\end{array}$ & 0 & $\begin{array}{l}64 \pm 18 \\
(n=9)\end{array}$ & $\mathrm{n} / \mathrm{a}$ & 1.5 & $\begin{array}{l}14 \pm 1 \\
(n=3)\end{array}$ & $\begin{array}{l}69 \pm 5 \\
(n=3)\end{array}$ \\
\hline & $16: 30-19: 30$ & $\begin{array}{l}79 \pm 9 \\
(n=3)\end{array}$ & $\begin{array}{l}67 \pm 6 \\
(n=9)\end{array}$ & $\begin{array}{l}67 \pm 6 \\
(n=9)\end{array}$ & 0 & $\begin{array}{l}51 \pm 5 \\
(n=9)\end{array}$ & $\mathrm{n} / \mathrm{a}$ & 1.2 & $\begin{array}{l}22 \pm 2 \\
(n=3)\end{array}$ & $\begin{array}{l}257 \pm 19 \\
(n=3)\end{array}$ \\
\hline & 22:00-01:00 & $\begin{array}{l}78 \pm 17 \\
(n=3)\end{array}$ & $\begin{array}{l}84 \pm 17 \\
(n=9)\end{array}$ & $\begin{array}{l}84 \pm 17 \\
(n=9)\end{array}$ & 0 & $\begin{array}{l}58 \pm 13 \\
(n=9)\end{array}$ & $\mathrm{n} / \mathrm{a}$ & 0.9 & $\begin{array}{l}11 \pm 4 \\
(n=3)\end{array}$ & $\begin{array}{l}29 \pm 1 \\
(n=3)\end{array}$ \\
\hline & \multicolumn{2}{|c|}{ Daily integral $\left[\mathrm{nmol} \mathrm{d} \mathbf{d}^{-1} \mathrm{~L}^{-1}\right]$} & 1833 & 1833 & $\mathbf{0}$ & 1476 & & $1.2[\mathrm{~h}]$ & 316 & 2367 \\
\hline \multicolumn{11}{|c|}{ 20/21-Aug-2013 } \\
\hline & 07:30-10:30 & $\begin{array}{l}568 \pm 18 \\
(n=3)\end{array}$ & $\begin{array}{l}171 \pm 13 \\
(n=9)\end{array}$ & $\begin{array}{l}120 \pm 49 \\
(n=9)\end{array}$ & -51 & $\begin{array}{l}28 \pm 2 \\
(n=9)\end{array}$ & $\mathrm{n} / \mathrm{a}$ & 3.3 & $\begin{array}{l}0.4 \pm 0.3 \\
(n=3)\end{array}$ & $\begin{array}{l}597 \pm 7 \\
(n=3)\end{array}$ \\
\hline & $14: 00-17: 00$ & $\begin{array}{l}45 \pm 9 \\
(n=3)\end{array}$ & $\begin{array}{l}94 \pm 38 \\
(n=9)\end{array}$ & $\begin{array}{l}94 \pm 38 \\
(n=9)\end{array}$ & 0 & $\begin{array}{l}36 \pm 21 \\
(n=9)\end{array}$ & $\mathrm{n} / \mathrm{a}$ & 0.5 & $\begin{array}{l}3.5 \pm 0.2 \\
(n=3)\end{array}$ & $\begin{array}{l}1352 \pm 8 \\
(n=3)\end{array}$ \\
\hline & $18: 30-21: 30$ & $\begin{array}{l}32 \pm 4 \\
(n=3)\end{array}$ & $\begin{array}{l}67 \pm 24 \\
(n=9)\end{array}$ & $\begin{array}{l}67 \pm 24 \\
(n=9)\end{array}$ & 0 & $\begin{array}{l}25 \pm 12 \\
(n=9)\end{array}$ & $32 \pm 22$ & 0.5 & $\begin{array}{l}2.0 \pm 0.3 \\
(n=3)\end{array}$ & $\begin{array}{l}287 \pm 13 \\
(n=3)\end{array}$ \\
\hline & $23: 30-02: 30$ & $\begin{array}{l}33 \pm 10 \\
(n=3)\end{array}$ & $\begin{array}{l}92 \pm 50 \\
(n=9)\end{array}$ & $\begin{array}{l}92 \pm 50 \\
(n=9)\end{array}$ & 0 & $\begin{array}{l}37 \pm 25 \\
(n=9)\end{array}$ & $\mathrm{n} / \mathrm{a}$ & 0.4 & $\begin{array}{l}0.79 \pm 0.03 \\
(n=3)\end{array}$ & $\begin{array}{l}17 \pm 1 \\
(n=3)\end{array}$ \\
\hline & \multicolumn{2}{|c|}{ Daily integral $\left[\mathrm{nmol} \mathrm{d}{ }^{-1} \mathbf{L}^{-1}\right]$} & 2561 & 2306 & -256 & 809 & & $1.2[\mathrm{~h}]$ & 36 & 11873 \\
\hline & AVERAGE & $\begin{array}{l}130 \pm 179 \\
(n=8)\end{array}$ & $\begin{array}{l}90 \pm 35 \\
(n=8)\end{array}$ & $\begin{array}{l}84 \pm 19 \\
(n=8)\end{array}$ & & $\begin{array}{l}47 \pm 18 \\
(n=8)\end{array}$ & & $\begin{array}{l}1.2 \pm 1.0 \\
(n=8)\end{array}$ & & \\
\hline
\end{tabular}

Bulk ammonium concentrations indicate concentrations before ${ }^{15} \mathrm{~N}$-ammonium additions $(20-30 \mathrm{nM})$. Data are given as mean \pm s.d.

$n / a$ not analysed

after $6 \mathrm{~h}$ [34]. A 5-point calibration covering the expected concentration range $(0-500 \mathrm{nM})$ was prepared, yielding a strong linear correlation between raw fluorescence and ammonium concentrations $\left(R^{2}>0.99\right)$. (iii) Phytoplankton composition-50 mL were preserved with Lugol solution for later microscopy. (iv) Single-cell ammonium assimilation and $C$-fixation-50 $\mathrm{mL}$ were preserved with paraformaldehyde (2\% final concentration) and filtered onto polycarbonate membrane filters $(0.22 \mu \mathrm{m}$ GTTP, $25 \mathrm{~mm}$, Merck Millipore) for (nano)SIMS analyses. (v) Bulk $N_{2}-/ C$-fixation and ammonium assimilation-500-600 mL were filtered onto pre-combusted $\mathrm{GF} / \mathrm{F}$ filters (25 mm, Whatman) and analysed on an isotope-ratio mass spectrometer interfaced to an elemental analyser (EA-IRMS).

\section{Phytoplankton composition and biomass}

Lugol-preserved samples were transferred into Utermoehl sedimentation chambers (Hydrobios) to identify and count phytoplankton taxa under an inverted light microscope (NIKON Eclipse Ti-U, $\times 150-400$ magnification). Heterotrophic bacteria (DAPI-stained) and unicellular picocyanobacteria (autofluorescent) were counted on GTTP filters under a fluorescence microscope (Zeiss Axio Imager, $\times 1000$ magnification). Cell sizes were measured on $\geq 40$ cells for each taxon to reach representative mean values. Cellular biovolumes and biomass were calculated as specified in supplementary Table S1.

\section{Stable-isotope analyses}

The ${ }^{15} \mathrm{~N}$-label\% of dissolved $\mathrm{N}_{2}$ was analysed by membraneinlet mass spectrometry (MIMS; GAM200, IPI, Bremen, Germany, relative precision $\pm 1 \%$ ). The ${ }^{13} \mathrm{C}$-label\% of dissolved inorganic carbon (DIC) was determined by trace gas isotope-ratio mass spectrometry (UC Davis California, US, precision $\pm 0.1 \%$ o). ${ }^{15} \mathrm{~N}$-ammonium concentrations were measured after chemical conversion to $\mathrm{N}_{2}$ with alkaline hypobromite [35]. Production of ${ }^{15} \mathrm{~N}$-nitrate and ${ }^{15} \mathrm{~N}$-nitrite in ${ }^{15} \mathrm{~N}$-ammonium incubations (i.e., nitrification) was quantified after conversion of nitrate to nitrite with cadmium, and nitrite to $\mathrm{N}_{2}$ with sulfamic acid [36] in samples from August 2013. ${ }^{15} \mathrm{~N}$-standards were used to determine conversion factors. The $\mathrm{N}_{2}$ isotope ratios were analysed by gas chromatographic isotope-ratio mass spectrometry (GC-IRMS, concentration precision $\pm 5 \%$ for ${ }^{15} \mathrm{~N}$-standards of $0-100 \mathrm{nM}$ ) on a Thermo Delta V isotope-ratio mass spectrometer [37]. Air was used as a standard and controls samples (without amendments) to determine the natural ${ }^{15} \mathrm{~N}$ mol fraction in the respective $\mathrm{N}$ pools. GF/F filters were freeze-dried, fumed over $\mathrm{HCl}$, pelletized into tin cups and analysed by EA-IRMS (UC Davis, precision $\pm 0.2 \%$ o for ${ }^{13} \mathrm{C}$ and $\pm 0.3 \%$ o for ${ }^{15} \mathrm{~N}$ ). Vienna 
PeeDee Belemnite and air served as $\mathrm{C}$ and $\mathrm{N}$ standards, respectively. Rates of bulk $\mathrm{N}_{2}$-fixation, $\mathrm{C}$-fixation and net ammonium assimilation were calculated as described in supplementary Text S1. To extrapolate to rates per day, the rates measured at four different times of the day (Table 1) were linearly time-integrated over $24 \mathrm{~h}$. Besides ammonium assimilation (accounting for ${ }^{15} \mathrm{~N}-\mathrm{PON}$ on GF/F filters), we also calculated gross consumption (accounting for the actual ${ }^{15} \mathrm{~N}$-ammonium decrease in the water) and production rates (Text S1). Ammonium production was specified to derive either from ammonium regeneration or from new ammonium released during $\mathrm{N}_{2}$-fixation. The latter was assumed to account for half of the $\mathrm{N}_{2}$-fixation rates, as shown for cells sampled concurrently with the ones herein [38] and during previous years $[7,23]$.

Due to ${ }^{15} \mathrm{~N}$-ammonium additions, bulk concentrations increased by $5-46 \%$, potentially stimulating ammonium assimilation. We therefore corrected all rates by accounting for ammonium uptake kinetics, as done previously [27, 39]. A half-saturation constant of $50 \mathrm{nM}$ was assumed, in the upper range of $15-60 \mathrm{nM}$ measured for natural plankton communities under N-depletion [27, 40, 41]. All equations and the resulting overestimations are given in supplementary Text $\mathrm{S} 1$.

\section{Secondary-ion mass spectrometry (SIMS and nanoSIMS)}

${ }^{15} \mathrm{~N}$-ammonium and ${ }^{13} \mathrm{C}$ incorporation $\left(\right.$ after ${ }^{15} \mathrm{~N}-$ ammonium and ${ }^{13} \mathrm{C}$-DIC incubations) into single cells were analysed using two types of SIMS instruments (Cameca, France): IMS 1280 and NanoSIMS 50 L (at the Natural History Museum Stockholm and the MPI for Marine Microbiology, respectively). The NanoSIMS $50 \mathrm{~L}$ instrument offers a higher spatial resolution $(50-100 \mathrm{~nm})$ than the IMS $1280(1000 \mathrm{~nm})$ but the latter allows for a higher sample throughput and its higher primary-ion beam current facilitates the removal of consolidated cell walls. Accordingly, we analysed heterotrophic bacteria and unicellular picocyanobacteria (cf. Synechococcus spp.) exclusively on the NanoSIMS 50 L, and Chaetoceros sp. and dinoflagellates (Dinophysis sp., Heterocapsa sp.) on the IMS 1280. Aphanizomenon sp., Dolichospermum spp., Nodularia spumigena, colony-forming picocyanobacteria (Aphanocapsa sp., Cyanodictyon sp. and Aphanothece paralleliformis) and Pseudanabaena sp. were analysed with both instruments. Heterotrophic bacteria and Synechococcus were distinguished as free-living and attached (to other phytoplankton cells), as validated under a fluorescence microscope prior nanoSIMS analyses. Analyses were done on cells incubated during 07:30-10:30 in June 2012 and 18:3021:30 in August 2013, since samples from those periods offered the highest cell abundances of the targeted plankton groups. SIMS analyses were conducted as presented elsewhere [38], except that diatoms and dinoflagellates were pre-sputtered with a higher $\mathrm{Cs}^{+}$beam (4-6 nA for 240-480 s instead of $3 \mathrm{nA}$ for $100 \mathrm{~s}$ ) and imaged with $70 \mathrm{pA}$ (instead of $40-60 \mathrm{pA}$ ) to remove the solid frustules/theca and penetrate into their rather thick cells. Regions of interest (ROIs) were drawn manually on the ${ }^{12} \mathrm{C}^{14} \mathrm{~N}$ ion images using the software Look@nanoSIMS [42] and WinImage (for IMS 1280 analyses). Isotope ratios for each ROI were averaged over 40-60 planes (nanoSIMS 50 L) and 100 planes (IMS 1280), and discarded if the standard error was $>5 \%$. Cells from control bottles without isotope additions served as standards. The ${ }^{15} \mathrm{~N}$-atom\% excess for control cells was on average $0.001 \pm 0.001(n=235)$ and $0.000 \pm 0.001(n=51)$, and the ${ }^{13} \mathrm{C}$-atom\% excess $0.001 \pm 0.001(n=235)$ and $0.000 \pm$ $0.004(n=51)$ for analyses on the IMS 1280 and nanoSIMS $50 \mathrm{~L}$, respectively. We mostly analysed $>50$ cells to reach representative mean values for each taxon [43, 44] (exceptions can be read from the number of replicates in Table 2).

Activities measured by SIMS are expressed as elementspecific assimilation rates $\left(\mathrm{h}^{-1}\right)$, calculated as described in the supplementary (Text S1). Statistical differences between taxa were calculated with the post-hoc Tukey's honest significant difference (HSD) test in R 3.3.0. To obtain cellspecific rates (fmol cell $\mathrm{h}^{-1}$ ), $\mathrm{N}$-specific ammonium assimilation and $\mathrm{C}$-specific $\mathrm{C}$-fixation rates $\left(\mathrm{h}^{-1}\right)$ were multiplied by cellular $\mathrm{N}$-contents and $\mathrm{C}$-contents (fmol cell ${ }^{-1}$ ), respectively. The $\mathrm{C}$-contents and $\mathrm{N}$-contents derived from empirical biovolume to biomass relationships (Table S1) which are routinely used for the long-term monitoring of Baltic Sea plankton [45] or have been measured directly for cyanobacteria at the sampling station [43]. Cell abundances were multiplied with cell-specific assimilation rates to quantify taxa-specific contributions to total ammonium assimilation. Uncertainties ( \pm s.d.) in single-cell activities and taxa-specific contributions to total assimilation derived from combined uncertainties of each variable, following the laws of error propagation. To verify whether ammonium assimilation was diffusion-limited, we calculated maximum ammonium fluxes explained by mass transfer theory, i.e., diffusion-limited ammonium supply to single cells. Fluxes at Synechococcus cells were calculated from the analytical solutions of diffusion to a sphere [46] and at Chaetoceros for cylindrical cell-chains [47] (Text S1).

\section{Results}

\section{Environmental data}

Water temperature was 14.5 and $17.0^{\circ} \mathrm{C}$ during sampling in June 2012 and August 2013, respectively; salinity was 6.2 and the mixed layer depth $25 \mathrm{~m}$ during both occasions (Fig. S2a). Nutrient concentrations were $0.03-0.57 \mu \mathrm{mol} \mathrm{L}^{-1}$ 
for ammonium (Tables 1), $0.02-0.04 \mu \mathrm{mol} \mathrm{L}^{-1}$ for nitrate + nitrite and $0.07-0.18 \mu \mathrm{mol} \mathrm{\textrm {L } ^ { - 1 }}$ for phosphate, similar to those reported by the Monitoring Program (Fig. S2b). POC and PON contents were $419 \pm 60 \mu \mathrm{g} \mathrm{C} \mathrm{L} \mathrm{L}^{-1}$ and $60 \pm 8 \mu \mathrm{g} \mathrm{N} \mathrm{L}{ }^{-1}(n=61)$ during June, and $380 \pm$ $38 \mu \mathrm{g} \mathrm{C} \mathrm{L}^{-1}$ and $64 \pm 4 \mu \mathrm{g} \mathrm{N} \mathrm{L}^{-1}(n=60)$ during August (Fig. S3).

The bacterioplankton and phytoplankton biomass

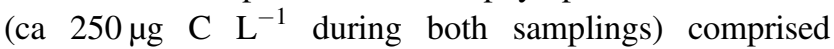
mainly Cyanobacteria (45-56\% of the C-biomass), heterotrophic bacteria (23-49\%), and to a lesser extent Dinophyta (0.3-12\%) and Bacillariophyceae (4\%, Fig. S3). The cyanobacterial biomass consisted of two orders (Chroococcales, 43-94\% and Oscillatoriales, <1\%) which did not fix $\mathrm{N}_{2}$ [38] and one $\mathrm{N}_{2}$-fixing order (Nostocales, $6-57 \%$ ). Thus, $3-31 \%$ of the bacterioplankton and phytoplankton biomass were diazotrophs. Chroococcales were dominated by unicellular picocyanobacteria $(>90 \%)$ which were classified as Synechococcus-type cells (cf. Synechococcus spp.).

\section{Single-cell ammonium assimilation and C-fixation}

Single-cell activities are presented as element-specific rates $\left(\mathrm{h}^{-1}\right)$ which are independent of cell size and thus allow to directly compare activities among different cell types and sizes. For instance, $\mathrm{N}$-specific ammonium assimilation rates of $0.005 \mathrm{~h}^{-1}$ imply that $0.5 \%$ of the cellular $\mathrm{N}$-content was assimilated per hour. Note that the assimilation rates are only valid for the time of the day when incubations for SIMS analyses were conducted while different activities can be expected during other times of the day.

Taxa analysed with SIMS included $\mathrm{N}_{2}$-fixing cyanobacteria, non- $\mathrm{N}_{2}$-fixing cyanobacteria, heterotrophic bacteria and eukaryotes (Fig. 1), covering most of the C-biomass of the enumerated bacterio plankton and phytoplankton $(\geq 84 \%)$. The taxa not analysed were less abundant (e.g., ciliate Mesodinium, diatom Cyclotella, Haptophyceae Chrysochromulina, and Cryptophyceae Teleaulax and Plagioselmis, Fig. S3). N-assimilation rates were highly variable, with mean $\mathrm{N}$-specific assimilation rates ranging from 0.0008 to $0.054 \mathrm{~h}^{-1}$ (see Fig. 2 and Table 2 for details). Mean N-specific ammonium assimilation was lowest in filamentous $\mathrm{N}_{2}$-fixing cyanobacteria (0.0008-0.007 $\left.\mathrm{h}^{-1}\right)$ of which Dolichospermum had the highest rates, followed by Aphanizomenon and Nodularia. Cells of dinoflagellates (Dinophysis, Heterocapsa) were rare. Thus, their mean values obtained from only twelve cells (six per taxa) may poorly represent their entire population but indicated that ammonium assimilation was low $\left(0.006 \mathrm{~h}^{-1}\right)$. The quantitatively most significant groups for total assimilation were unicellular picocyanobacteria (Synechococcus) and heterotrophic bacteria-both small cells with high population biomass (Fig. 3) and high ammonium assimilation rates (mean values: $0.012-0.054$ and $0.005-0.022 \mathrm{~h}^{-1}$, respectively, Table 2). Synechococcus accounted for $38 \pm 31$ and $23 \pm$ $17 \%$, and heterotrophic bacteria for $17 \pm 18$ and $24 \pm 27 \%$ of the total assimilation in June 2012 and August 2013, respectively (Fig. 3c). Chain-forming diatoms (Chaetoceros) showed mean $\mathrm{N}$-assimilation rates as high as $0.034 \mathrm{~h}^{-1}$ (Table 2). By comparison, theoretical ammonium assimilation rates constrained by diffusionlimited ammonium supply were $0.033-0.066 \mathrm{~h}^{-1}$ for chain-forming Chaetoceros (with 2-17 cells per chain) and $1.414 \mathrm{~h}^{-1}$ for unicellular Synechococcus (at ambient ammonium concentrations of $111 \mathrm{nM}$, as measured during the morning sampling in June 2012), indicating diffusion-limited assimilation in large Chaetoceros but no diffusion-limitation for Synechococcus.

Mean C-specific C-fixation rates ranged from 0.003 to $0.025 \mathrm{~h}^{-1}$ for phototrophic taxa. They were highest for Chaetoceros $\left(0.020 \mathrm{~h}^{-1}\right.$ in June 2012 and $0.024 \mathrm{~h}^{-1}$ in August 2013) and unicellular picocyanobacteria (0.025 and $0.018 \mathrm{~h}^{-1}$ for attached and free-living Synechococcus, respectively in August 2012). The remaining phototrophic cells showed lower C-fixation (mean: $0.003-0.012 \mathrm{~h}^{-1}$, Fig. 2 and Table 2).

\section{Community $\mathrm{N}_{2}$-fixation and C-fixation, and ammonium cycling}

$\mathrm{N}_{2}$-fixation rates were $0.4-21.9 \mathrm{nmol} \mathrm{N} \mathrm{h}^{-1} \mathrm{~L}^{-1}$ (Table 1) with higher rates in June 2012 compared to August 2013 when the biomass of $\mathrm{N}_{2}$-fixing cyanobacteria was low $\left(<10 \mu \mathrm{g} \mathrm{C} \mathrm{L}{ }^{-1}\right.$, Fig. S3). New ammonium from dailyintegrated $\mathrm{N}_{2}$-fixation potentially accounted for 9 and $1 \%$ of total ammonium production in June 2012 and August 2013, respectively, while the remaining $\geq 91 \%$ derived from regeneration. Added ${ }^{15} \mathrm{~N}$-ammonium concentrations decreased exponentially over time. On average, $57 \pm 28 \%$ ( $n=16$ ) of the consumed ${ }^{15} \mathrm{~N}$ was recovered as ${ }^{15} \mathrm{~N}-\mathrm{PON}$ on $\mathrm{GF} / \mathrm{F}$ filters. Bulk concentrations, however, remained at steady-state since gross consumption and production rates balanced each other (Fig. 4a-d). The turnover time through consumption was $1.2 \pm 1.0 \mathrm{~h}$. A diel pattern in ammonium processes was not evident (Table 1). Nitrification was not detectable since changes in ${ }^{15} \mathrm{~N}$-nitrate/nitrite concentrations overtime were not significant (linear regression analyses, $p>0.10)$.

C-fixation rates were $17-1352 \mathrm{nmol} \mathrm{C} \mathrm{h}^{-1} \mathrm{~L}^{-1}$, peaking during day-time and decreasing towards midnight (Table 1). In August 2013, 97\% of the N-demand for diurnal C-fixation was supported by ammonium regeneration (Fig. $4 \mathrm{e}$ ) and $2 \%$ by $\mathrm{N}_{2}$-fixation (assuming Redfield ratio and given that $24 \%$ of the produced ammonium was assimilated by heterotrophic 
Table 2 Single-cell ammonium assimilation and C-fixation rates of different plankton groups

\begin{tabular}{|c|c|c|c|c|c|c|c|c|c|c|}
\hline & \multirow{2}{*}{\multicolumn{2}{|c|}{$\begin{array}{l}\mathrm{N} \text {-specific } \mathrm{NH}_{4}^{+} \\
\text {-assimilation } \\
\mathrm{h}^{-1}\end{array}$}} & \multirow{2}{*}{\multicolumn{2}{|c|}{$\begin{array}{l}\text { Cell-specific } \mathrm{NH}_{4}{ }^{+} \text {-assimilation } \\
{\text { fmol } \mathrm{NH}_{4}{ }^{+} \text {cell }^{-1} \mathrm{~h}^{-1}}^{-1}\end{array}$}} & \multirow{2}{*}{\multicolumn{2}{|c|}{$\begin{array}{l}\text { C-specific } \\
\text { C-fixation } \\
\mathrm{h}^{-1}\end{array}$}} & \multirow{2}{*}{\multicolumn{2}{|c|}{$\begin{array}{l}\text { Cell-specific C-fixation } \\
\frac{\text { fmol C cell }}{-1} \mathrm{~h}^{-1}\end{array}$}} & \multirow{2}{*}{\multicolumn{2}{|c|}{$\mathrm{n}$}} \\
\hline & & & & & & & & & & \\
\hline & $\begin{array}{l}\text { June } \\
2012\end{array}$ & $\begin{array}{l}\text { Aug } \\
2013\end{array}$ & $\begin{array}{l}\text { June } \\
2012\end{array}$ & $\begin{array}{l}\text { Aug } \\
2013\end{array}$ & $\begin{array}{l}\text { June } \\
2012\end{array}$ & $\begin{array}{l}\text { Aug } \\
2013\end{array}$ & $\begin{array}{l}\text { June } \\
2012\end{array}$ & $\begin{array}{l}\text { Aug } \\
2013\end{array}$ & $\begin{array}{l}\text { June } \\
2012\end{array}$ & $\begin{array}{l}\text { Aug } \\
2013\end{array}$ \\
\hline \multicolumn{11}{|l|}{$\mathrm{N}_{2}$-fixing cyanobacteria } \\
\hline \multirow[t]{2}{*}{ Aphanizomenon sp. } & $\begin{array}{l}0.003 \pm \\
0.001\end{array}$ & $\begin{array}{l}0.001 \pm \\
0.001\end{array}$ & $1.1 \pm 0.5$ & $0.5 \pm 0.2$ & $\begin{array}{l}0.012 \pm \\
0.006\end{array}$ & $\begin{array}{l}0.005 \pm \\
0.002\end{array}$ & $25.7 \pm 13.4$ & $10.9 \pm 5.2$ & 65 & 53 \\
\hline & $\begin{array}{l}(0.001- \\
0.007)\end{array}$ & $\begin{array}{l}(0.0003- \\
0.003)\end{array}$ & $(0.3-2.5)$ & $(0.1-1.0)$ & $\begin{array}{l}(0.003- \\
0.029)\end{array}$ & $\begin{array}{l}(0.001- \\
0.010)\end{array}$ & $(7.3-61.0)$ & $(1.8-21.3)$ & & \\
\hline \multirow[t]{2}{*}{ Nodularia spumigena } & - & $\begin{array}{l}0.0008 \pm \\
0.0004\end{array}$ & $\mathrm{n} / \mathrm{p}$ & $0.6 \pm 0.3$ & $\mathrm{n} / \mathrm{p}$ & $\begin{array}{l}0.009 \pm \\
0.005\end{array}$ & $\mathrm{n} / \mathrm{p}$ & $46.5 \pm 26.7$ & $\mathrm{n} / \mathrm{p}$ & 136 \\
\hline & - & $\begin{array}{l}(0.0001- \\
0.003)\end{array}$ & & $(0.1-2.2)$ & & $\begin{array}{l}(0.002- \\
0.021)\end{array}$ & & $(9.5-107.3)$ & & \\
\hline \multirow[t]{2}{*}{ Dolichospermum spp. } & $\begin{array}{l}0.007 \pm \\
0.003\end{array}$ & $\begin{array}{l}0.003 \pm \\
0.003\end{array}$ & $1.5 \pm 0.9$ & $0.6 \pm 0.7$ & $\begin{array}{l}0.009 \pm \\
0.002\end{array}$ & $\begin{array}{l}0.011 \pm \\
0.014\end{array}$ & $12.6 \pm 5.8$ & $14.7 \pm 19.5$ & 102 & 164 \\
\hline & $\begin{array}{l}(0.003- \\
0.021)\end{array}$ & $\begin{array}{l}(0.0001- \\
0.014)\end{array}$ & $(0.6-4.5)$ & $(0.02-3.1)$ & $\begin{array}{l}(0.005- \\
0.016)\end{array}$ & $\begin{array}{l}(0.001 \pm \\
0.058)\end{array}$ & $(6.6-22.0)$ & $(0.8-78.9)$ & & \\
\hline \multicolumn{11}{|l|}{ Non- $\mathrm{N}_{2}$-fixing cyanobacteria } \\
\hline \multirow[t]{2}{*}{ Filamentous Pseudanabaena sp. } & $\begin{array}{l}0.029 \pm \\
0.010\end{array}$ & $\begin{array}{l}0.006 \pm \\
0.002\end{array}$ & $0.8 \pm 0.3$ & $0.18 \pm 0.06$ & $\begin{array}{l}0.005 \pm \\
0.003\end{array}$ & $\begin{array}{l}0.009 \pm \\
0.005\end{array}$ & $1.0 \pm 0.5$ & $1.6 \pm 1.0$ & 27 & 69 \\
\hline & $\begin{array}{l}(0.015- \\
0.051)\end{array}$ & $\begin{array}{l}(0.003- \\
0.012)\end{array}$ & $(0.4-1.5)$ & $(0.08-0.35)$ & $\begin{array}{l}(0.002- \\
0.017)\end{array}$ & $\begin{array}{l}(0.001- \\
0.026)\end{array}$ & $(0.4-3.2)$ & $(0.2-5.0)$ & & \\
\hline \multirow[t]{2}{*}{$\begin{array}{l}\text { Colonial picocyanobacteria } \\
\text { Aphanocapsa sp./Cyanodictyon sp. }\end{array}$} & $\begin{array}{l}0.023 \pm \\
0.010\end{array}$ & $\begin{array}{l}0.008 \pm \\
0.004\end{array}$ & $\begin{array}{l}0.21 \pm 0.11 / \\
0.12 \pm 0.06\end{array}$ & $\begin{array}{l}0.07 \pm 0.04 / \\
0.04 \pm 0.02\end{array}$ & $\begin{array}{l}0.006 \pm \\
0.003\end{array}$ & $\begin{array}{l}0.008 \pm \\
0.005\end{array}$ & $\begin{array}{l}0.33 \pm 0.19 / \\
0.19 \pm 0.11\end{array}$ & $\begin{array}{l}0.46 \pm 0.34 / \\
0.27 \pm 0.20\end{array}$ & 174 & 116 \\
\hline & $\begin{array}{l}(0.007- \\
0.058)\end{array}$ & $\begin{array}{l}(0.001- \\
0.024)\end{array}$ & $\begin{array}{l}(0.06-0.51) / \\
(0.04-0.30)\end{array}$ & $\begin{array}{l}(0.01-0.22) / \\
(0.01-0.13)\end{array}$ & $\begin{array}{l}(0.001- \\
0.012)\end{array}$ & $\begin{array}{l}(0.002- \\
0.024)\end{array}$ & $\begin{array}{l}(0.03-0.69) / \\
(0.02-0.40)\end{array}$ & $\begin{array}{l}(0.12-1.40) / \\
(0.07-0.81)\end{array}$ & & \\
\hline \multirow[t]{2}{*}{$\begin{array}{l}\text { Colonial picocyanobacteria } \\
\text { Aphanothece paralleliformis }\end{array}$} & $\begin{array}{l}0.017 \pm \\
0.005\end{array}$ & $\begin{array}{l}0.005 \pm \\
0.002\end{array}$ & $0.11 \pm 0.04$ & $0.03 \pm 0.02$ & $\begin{array}{l}0.003 \pm \\
0.001\end{array}$ & $\begin{array}{l}0.005 \pm \\
0.003\end{array}$ & $0.11 \pm 0.06$ & $0.21 \pm 0.14$ & 79 & 127 \\
\hline & $\begin{array}{l}(0.010- \\
0.027)\end{array}$ & $\begin{array}{l}(0.002- \\
0.018)\end{array}$ & $(0.06-0.16)$ & $(0.01-0.11)$ & $\begin{array}{l}(0.001- \\
0.005)\end{array}$ & $\begin{array}{l}(0.001- \\
0.013)\end{array}$ & $(0.02-0.21)$ & $(0.03-0.54)$ & & \\
\hline \multirow[t]{2}{*}{$\begin{array}{l}\text { Unicellular picocyanobacteria cf. } \\
\text { Synechococcus spp. (attached) }\end{array}$} & $\begin{array}{l}0.054 \pm \\
0.023\end{array}$ & $\begin{array}{l}0.015 \pm \\
0.003\end{array}$ & $0.14 \pm 0.07$ & $0.04 \pm 0.01$ & $\begin{array}{l}0.007 \pm \\
0.001\end{array}$ & $\begin{array}{l}0.025 \pm \\
0.013\end{array}$ & $0.11 \pm 0.03$ & $0.42 \pm 0.24$ & 20 & 19 \\
\hline & $\begin{array}{l}(0.026- \\
0.101)\end{array}$ & $\begin{array}{l}(0.010- \\
0.020)\end{array}$ & $(0.07-0.26)$ & $(0.03-0.05)$ & $\begin{array}{l}(0.004- \\
0.008)\end{array}$ & $\begin{array}{l}(0.002- \\
0.043)\end{array}$ & $(0.07-0.15)$ & $(0.04-0.74)$ & & \\
\hline \multirow[t]{2}{*}{$\begin{array}{l}\text { Unicellular picocyanobacteria cf. } \\
\text { Synechococcus spp. (free-living) }\end{array}$} & $\begin{array}{l}0.044 \pm \\
0.026\end{array}$ & $\begin{array}{l}0.012 \pm \\
0.005\end{array}$ & $0.11 \pm 0.07$ & $0.03 \pm 0.02$ & $\begin{array}{l}0.008 \pm \\
0.007\end{array}$ & $\begin{array}{l}0.018 \pm \\
0.009\end{array}$ & $0.13 \pm 0.13$ & $0.32 \pm 0.16$ & 71 & 126 \\
\hline & $\begin{array}{l}(0.008- \\
0.101)\end{array}$ & $\begin{array}{l}(0.002- \\
0.029)\end{array}$ & $(0.02-0.26)$ & $(0.01-0.07)$ & $\begin{array}{l}(0.001- \\
0.033)\end{array}$ & $\begin{array}{l}(0.001- \\
0.047)\end{array}$ & $(0.01-0.57)$ & $(0.02-0.82)$ & & \\
\hline \multicolumn{11}{|l|}{ Heterotrophic bacteria } \\
\hline \multirow[t]{2}{*}{ Heterotrophic bacteria (attached) } & $\begin{array}{l}0.016 \pm \\
0.010\end{array}$ & $\begin{array}{l}0.022 \pm \\
0.014\end{array}$ & $0.007 \pm 0.004$ & $0.009 \pm 0.006$ & - & - & - & - & 24 & 54 \\
\hline & $\begin{array}{l}(0.003- \\
0.050)\end{array}$ & $\begin{array}{l}(0.003- \\
0.061)\end{array}$ & $(0.001-0.021)$ & $(0.001-0.025)$ & & & & & & \\
\hline \multirow[t]{2}{*}{ Heterotrophic bacteria (free-living) } & $\begin{array}{l}0.011 \pm \\
0.010\end{array}$ & $\begin{array}{l}0.005 \pm \\
0.006\end{array}$ & $0.005 \pm 0.004$ & $0.002 \pm 0.002$ & - & - & - & - & 302 & 86 \\
\hline & $\begin{array}{l}(0.002- \\
0.057)\end{array}$ & $\begin{array}{l}(0.0003- \\
0.031)\end{array}$ & $(0.001-0.024)$ & $\begin{array}{l}(0.0001- \\
0.013)\end{array}$ & & & & & & \\
\hline \multicolumn{11}{|l|}{ Eukaryotes } \\
\hline \multirow[t]{2}{*}{ Diatom Chaetoceros sp. } & $\begin{array}{l}0.034 \pm \\
0.016\end{array}$ & $\begin{array}{l}0.007 \pm \\
0.002\end{array}$ & $13.9 \pm 8.1$ & $2.9 \pm 1.2$ & $\begin{array}{l}0.020 \pm \\
0.008\end{array}$ & $\begin{array}{l}0.024 \pm \\
0.011\end{array}$ & $55.9 \pm 28.1$ & $66.9 \pm 38.1$ & 65 & 23 \\
\hline & $\begin{array}{l}(0.005- \\
0.081)\end{array}$ & $\begin{array}{l}(0.003- \\
0.011)\end{array}$ & $(2.0-33.6)$ & $(1.0-4.6)$ & $\begin{array}{l}(0.002- \\
0.036)\end{array}$ & $\begin{array}{l}(0.007- \\
0.047)\end{array}$ & $(6.4-97.5)$ & $(18.6-128.8)$ & & \\
\hline \multirow[t]{2}{*}{$\begin{array}{l}\text { Dinoflagellates (Dinophysis, } \\
\text { Heterocapsa) }\end{array}$} & $\begin{array}{l}0.006 \pm \\
0.005\end{array}$ & $\mathrm{n} / \mathrm{a}$ & $\mathrm{n} / \mathrm{a}$ & $\mathrm{n} / \mathrm{a}$ & $\mathrm{n} / \mathrm{a}$ & $\mathrm{n} / \mathrm{a}$ & $\mathrm{n} / \mathrm{a}$ & $\mathrm{n} / \mathrm{a}$ & $\begin{array}{l}12(6 \\
+6)\end{array}$ & $\mathrm{n} / \mathrm{a}$ \\
\hline & $\begin{array}{l}(0.001- \\
0.017)\end{array}$ & & & & & & & & & \\
\hline
\end{tabular}

Rates were measured for cells incubated during 07:30-10:30 in June 2012 and 18:30-21:30 in August 2013. Data are given as mean \pm s.d. with their ranges in parentheses, $\mathrm{n}$ indicates the number of analysed cells

$\mathrm{n} / \mathrm{p}$ cells not present, $\mathrm{n} / \mathrm{a}$ not analysed

bacteria and not by primary producers, as shown in Fig. 3b). In June 2012, ammonium production even exceeded the $\mathrm{N}$-demand but $\mathrm{C}$-fixation was probably photo-inhibited (at up to $1250 \mu \mathrm{mol}$ photons $\mathrm{s}^{-1} \mathrm{~m}^{-2}$, Fig. S1) since C-fixation rates of the same plankton community measured in a parallel study at lower light were five times as high as those measured herein [38]. Assuming that actual C-fixation was five times higher, the $\mathrm{N}$-demand for diurnal $\mathrm{C}$-fixation would have been 
a A) Aphanizomenon sp. ( $\mathrm{N}_{2}$-fixing)

B) picocyanobact. colony (Aphanothece paralleliformis)

C) cf. Synechococcus spp.

D) heterotrophic bacteria

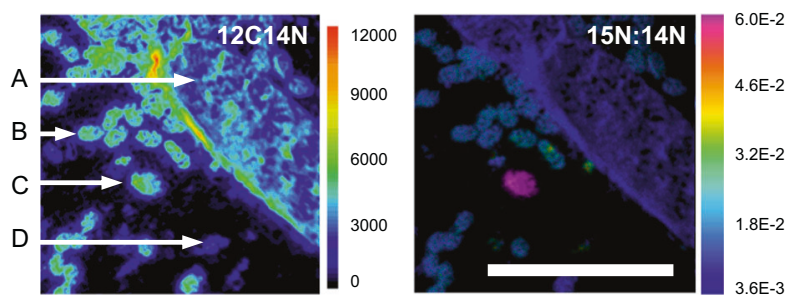

C picocyanobact. colony (Aphanothece paralleliformis)
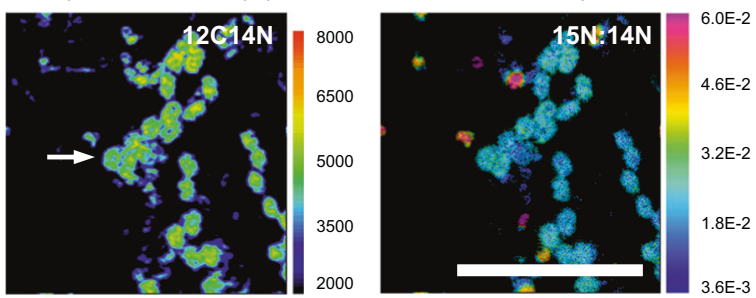

e

Dolichospermum spp. ( $\mathrm{N}_{2}$-fixing)
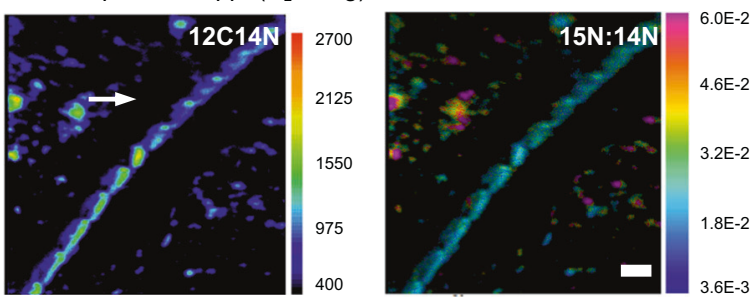

Fig. 1 Secondary-ion mass spectrometer (SIMS) images of ${ }^{12} \mathrm{C}^{14} \mathrm{~N}$ counts (left panel) and ${ }^{15} \mathrm{~N} /{ }^{14} \mathrm{~N}$ isotope ratios (right panel) after ${ }^{15} \mathrm{~N}$ ammonium incubations. Samples were analysed at high-resolution with the NanoSIMS $50 \mathrm{~L}(\mathbf{a}-\mathbf{c})$ and at lower resolution with the IMS-

sustained to $78 \%$ by ammonium regeneration (Fig. 4e) and to $16 \%$ by $\mathrm{N}_{2}$-fixation (at Redfield ratio and given that $17 \%$ of the ammonium were assimilated by heterotrophic bacteria).

\section{Discussion}

\section{Tight ammonium coupling and $\mathrm{N}_{2}$-fixation sustain long-term $\mathrm{N}$-availability for primary production}

Primary production based on $\mathrm{N}_{2}$-fixation and ammonium regeneration often dominates across diverse aquatic environments [1-3]. At the herein sampled coastal area, ammonium production derived mostly from regeneration and less from recent $\mathrm{N}_{2}$-fixation (Fig. 3c). Yet, parts of the regenerated ammonium may have its origin in $\mathrm{N}_{2}$-fixation hours, days or weeks prior to our sampling. Additional $\mathrm{N}$ may have been supplied as DON released from diazotrophs b

A) Pseudanabaena sp.

B) cf. Synechococcus spp. (attached)

C) cf. Synechococcus spp. (free-living)
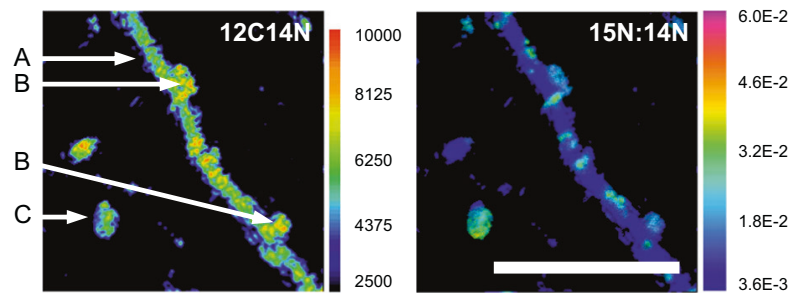

d

Chaetoceros sp.
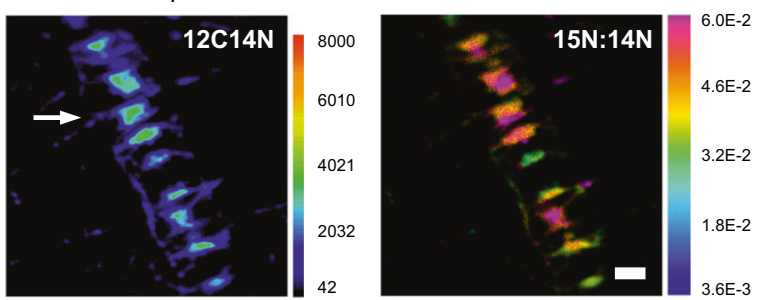

f

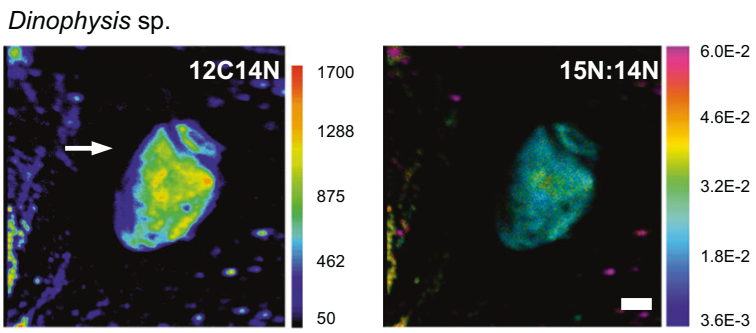

$1280(\mathbf{d}-\mathbf{f})$. Cell identification was done based on fluorescence microscope images taken prior SIMS analyses. White scale bars are $10 \mu \mathrm{m}$ (note the different scale bars in panels $\mathbf{a}-\mathbf{c}$ and $\mathbf{d}-\mathbf{f}$ )

$[9,16,18,48]$. Recently, amino acids have been shown to be newly synthetised during $\mathrm{N}_{2}$-fixation, and incorporated into bulk PON at rates of $0.5-7.0 \mathrm{nmol} \mathrm{L}^{-1} \mathrm{~h}^{-1}$ during summer in the Baltic Sea [18]. Those rates correspond to $1-8 \%$ of the ammonium consumption rates measured in our study (on average $90 \mathrm{nmol} \mathrm{L}^{-1} \mathrm{~h}^{-1}$, Table 1). Ammonium regeneration was the predominant $\mathrm{N}$-source for the autotrophic plankton community (78-97\%), as shown earlier in the Baltic Sea [49]. By comparison, new production, i.e., $\mathrm{N}_{2}$-fixation, supported $2-16 \%$ of the $\mathrm{N}$-demand for primary production, in rough agreement with our previous estimate that $\mathrm{N}_{2}$-fixation supports $21 \%$ of the C-fixation over summer in the euphotic zone of the Northern Baltic Proper [38].

Interestingly, primary production rates were as high as those typically measured during spring (Swedish Monitoring Program) when new production is based on nitrate. High primary production rates despite low nutrient 

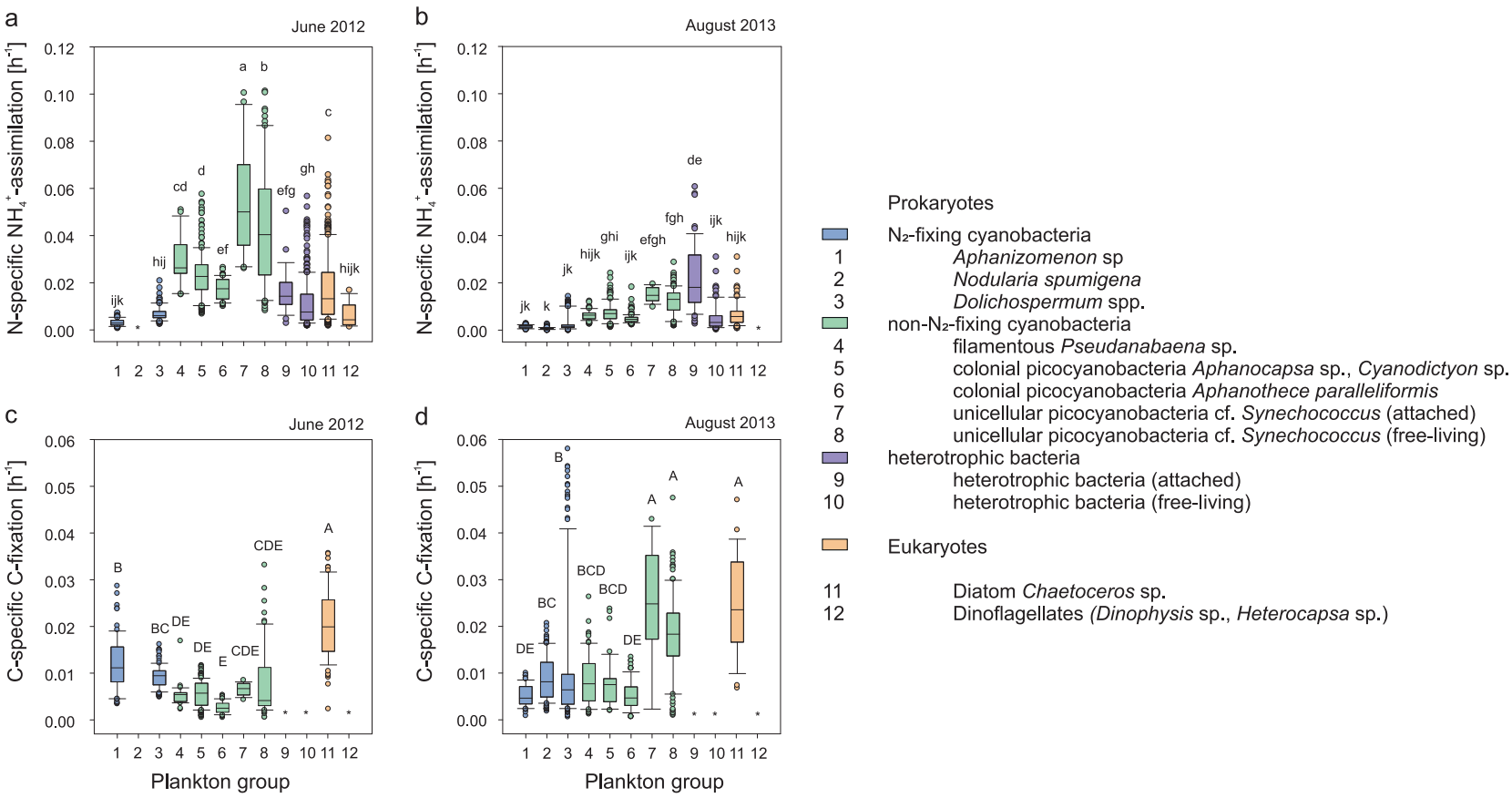

Fig. 2 Single-cell ammonium assimilation $(\mathbf{a}, \mathbf{b})$ and carbon fixation (c, d) analysed by secondary-ion mass spectrometry. Rates were measured for cells incubated during 07:30-10:30 in June 2012 (a, c) and 18:30-21:30 in August 2013 (b, d). Significantly different rates are indicated by different letters (ammonium assimilation and carbon fixation rates were tested separately, shown by non-capitalised and

capitalised letters, HSD-test, $p<0.05, \mathrm{Df}=1892$ and 1279 , respectively). Shown are the range (including 25 and $75 \%$ percentile, minimum, maximum and median) and outliers (circles). Note the different $\mathrm{x}$-axes for ammonium assimilation and C-fixation. Asterisks indicate that no data are available. Details are listed in Table 2

concentrations were reconciled by a tight coupling of production and consumption rates, following a close to $1: 1$ ratio (Fig. 4d) [see also refs. [3, 50]]. Therefore, the de facto $\mathrm{N}$-availability was extended by fast turnover times (on average $1 \mathrm{~h}$ ), which are common in $\mathrm{N}$-depleted marine estuaries and lakes [51-53] but shorter than under N-rich conditions $[51,54]$. The high $\mathrm{N}$-retention through regeneration and re-assimilation in the photic zone combined with low sedimentation losses, e.g., of slow-sinking picocyanobacteria and buoyant $\mathrm{N}_{2}$-fixing cyanobacteria [55] supports an increase of the total $\mathrm{N}$ inventory due to new $\mathrm{N}$ from $\mathrm{N}_{2}$-fixation [29, 31]. Thus, diazotrophic-derived and regenerated $\mathrm{N}$ is effectively retained and accumulated in the upper mixed layer from early towards late summer when the food demand by fish is highest [24].

\section{Quantitative ammonium assimilation assays: SIMS vs. EA-IRMS}

Ammonium consumption and production rates were 65$171 \mathrm{nmol} \mathrm{N} \mathrm{L}{ }^{-1} \mathrm{~h}^{-1}$ (Table 1), similar to those reported for coastal areas but higher than those previously measured in the Baltic Sea [56] and in worldwide oceanic and estuarine systems [summarised in refs. [4, 6]]. As a novelty-compared to numerous black-box-experiments, dating as far back as half a century ago [57], and also

more recent SIMS-based ammonium analyses in freshwater systems [58], marine sediments [59] and coraldinoflagellates symbioses [60]—we quantified ammonium assimilation for major taxa of the bacterioplankton and phytoplankton in marine waters. Recently, single-cell analyses by SIMS could fully explain community $\mathrm{N}_{2}$ fixation [38] measured on GF/F filters by EA-IRMS when large phytoplankton dominated the activity. In the herein presented study, taxa analysed by SIMS explained 48$63 \%$ of the gross ammonium consumption, whereas assimilation by cells collected onto GF/F filters explained 37-98\%. Hence, both approaches (EA-IRMS and SIMS) did not fully explain total ammonium consumption rates. Small heterotrophic bacteria greatly contributed to community biomass and ammonium assimilation (Fig. 3a, b) but GF/F filter have been shown to poorly retain bacterioplankton [56], thus underestimating their activities [27, 61]. Our SIMS data may underrate single-cell assimilation rates of the picoplankton due to uncertainties in their cellular $\mathrm{N}$-contents and uptake kinetics. To correct assimilation rates for any potential stimulation after ${ }^{15} \mathrm{~N}$-ammonium additions, we used a half-saturation constant value of $50 \mathrm{nM}$, which might be lower for small heterotrophic bacteria and picocyanobacteria, and potentially underestimate our rates after correction. Bulk Cfixation was indeed not stimulated by ${ }^{15} \mathrm{~N}$-ammonium 
a

JUNE

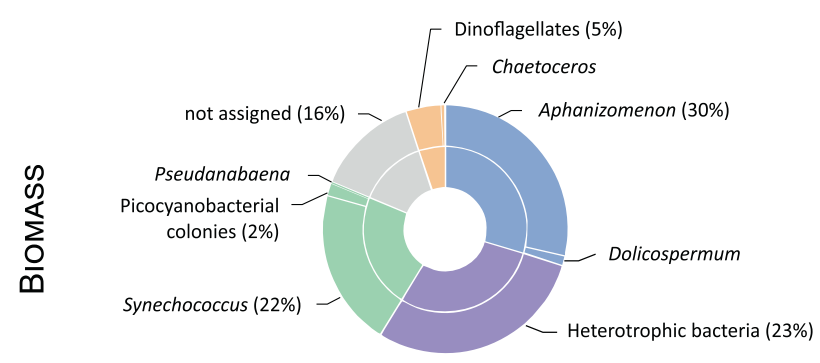

b
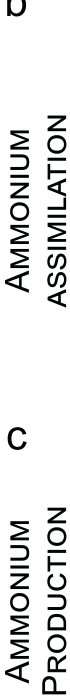

August
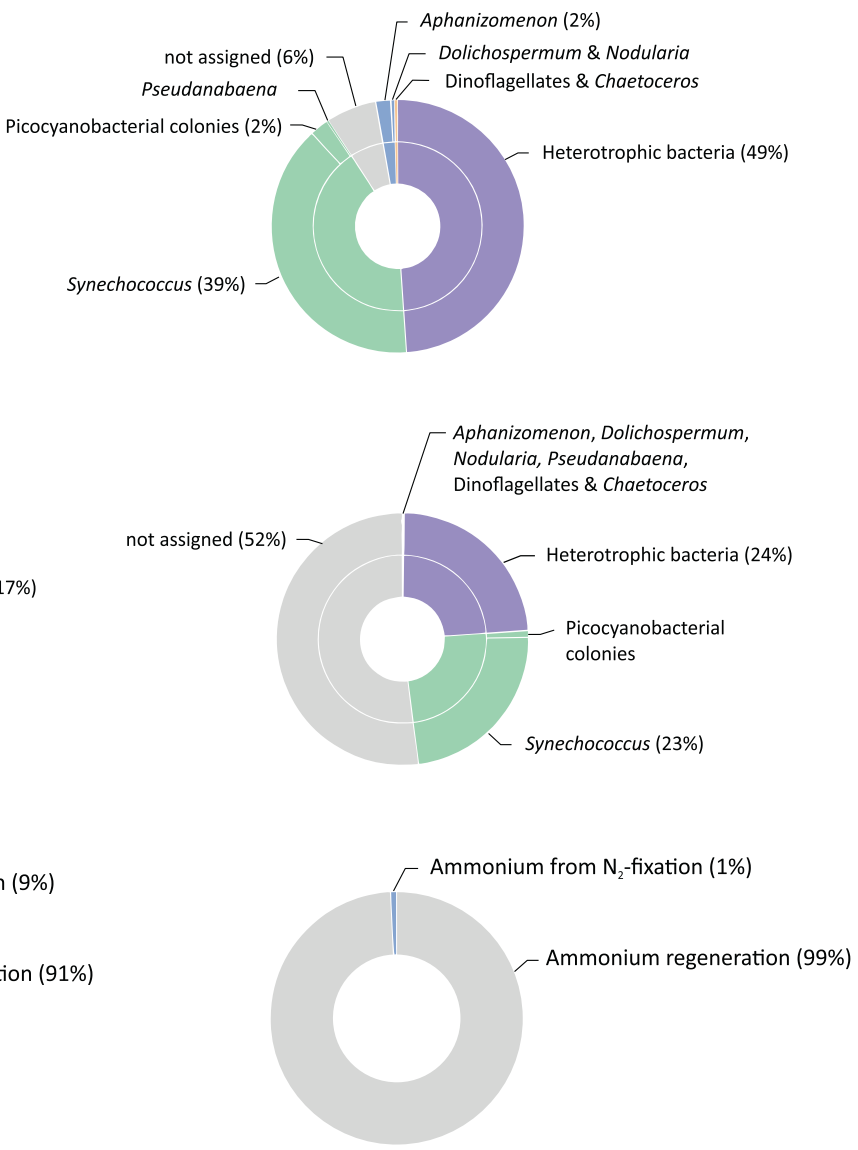

$\mathrm{N}_{2}$-fixing cyanobacteria

Non- $\mathrm{N}_{2}$-fixing cyanobacteria

\section{Eukaryotic phytoplankton}

Fig. 3 Relative carbon biomass (a) and ammonium assimilation (b) of bacterioplankton and phytoplankton in N-poor surface waters in the Baltic Sea. The not assigned biomass reflects the biomass of organisms which were microscopically identified and enumerated but not analysed by SIMS (see result section). Ammonium assimilation by the identified and analysed bacterio- and phytoplankton explained $48-63 \%$ of the total ammonium consumption (the remaining fraction

additions, as implied from similar C-fixation rates measured after ${ }^{15} \mathrm{~N}_{2}$ and ${ }^{15} \mathrm{~N}$-ammonium incubations (Fig. S4). Numerically inconspicuous taxa not analysed by SIMS might have also contributed to ammonium assimilation disproportionally to their population biomass, as shown for anaerobic bacteria [58] and diatoms [62]. The mismatch of ammonium assimilation and consumption might also be explained by nitrification but we could not detect any significant rates of this process. Nitrification was also not detectable in previous studies in N-depleted Baltic Sea surface waters during summer $[63,64]$ and nitrifiers are generally outcompeted by is indicated as not assigned). Ammonium production resulted partly from $\mathrm{N}_{2}$-fixation but mostly from ammonium regeneration of unknown sources (d). Percentages are given in brackets (for contributions $>1 \%$ ). The relative standard deviation of the taxa-specific contributions in panels (a, b) was $59 \pm 25 \%(n=42)$. Dinoflagellates included Dinophysis and Heterocapsa

phytoplankton under nitrate-replete regimes [65]. Consistently, high nitrification rates have been measured recently in other coastal areas of the Baltic Sea when nitrate concentrations were substantially higher $\left(>0.7 \mu \mathrm{mol} \mathrm{L}{ }^{-1}\right.$ ) than at our sampling station $[66,67]$.

\section{Single-cell ammonium assimilation by diazotrophs}

Using SIMS, we could analyse in situ assimilation rates across various functional plankton taxa with different or even similar cell sizes. Intriguingly, filamentous $\mathrm{N}_{2}$-fixing cyanobacteria did not substantially take up ammonium 
Fig. 4 Ammonium dynamics in surface waters during $\mathrm{N}$ depletion. Added ${ }^{15} \mathrm{~N}$ ammonium decreased exponentially with time (a) and was mostly recovered in the biomass filtered onto GF/F filters (b), while total ammonium concentrations (measured after ${ }^{15} \mathrm{~N}$-ammonium was added) remained at steadystate (c). Data are given as mean \pm s.d. $(n=3)$ and are shown for incubations from June 2012 (ac). Gross ammonium production and consumption rates (measured in June 2012 and August 2013) were positively correlated, following a close to 1:1 ratio (dashed line) (d). The rapid ammonium turn-over due to ammonium regeneration within $1 \mathrm{~h}$ could substantially sustain the $\mathrm{N}$-demand for primary production (e)
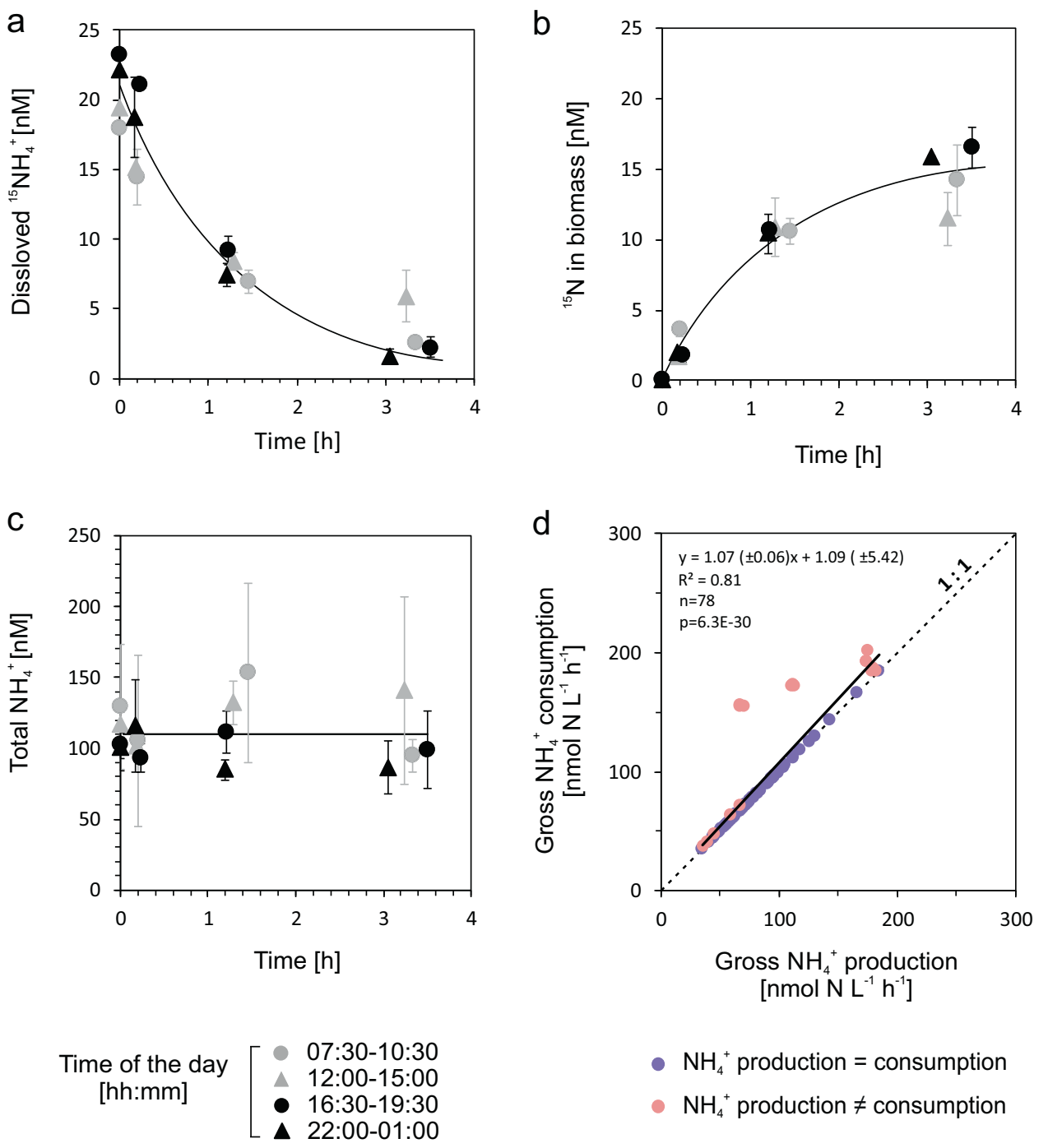

- $\mathrm{NH}_{4}^{+}$production = consumption

- $\mathrm{NH}_{4}{ }^{+}$production $\neq$consumption e

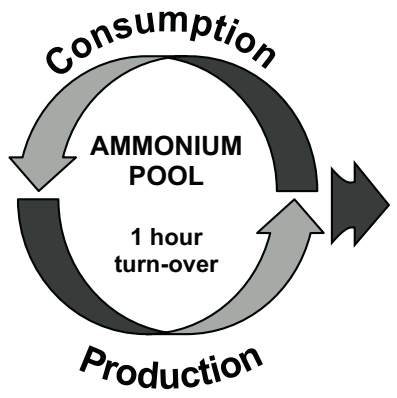

PrimaRY PRODUCTION (78-97\%) which is supported by long-term observations of natural isotopic compositions of these cyanobacteria in the Baltic Sea [68]. Aphanizomenon contributed maximally $4 \pm 3 \%$ to the total ammonium assimilation although they accounted for up to $30 \pm 12 \%$ of the C-biomass (Fig. 3a, b). Ammonium assimilation rates were low (Table 2), as already shown for Aphanizomenon sp., presumably due to colonyformation which reinforces diffusion-limited ammonium transport towards cells [23]. In a parallel study to that in June 2012, $\mathrm{N}_{2}$-fixation rates were as fast as 0.023 $0.097 \mathrm{~h}^{-1}$ for Aphanizomenon and Dolichospermum [38] while herein measured ammonium assimilation rates were $0.0008-0.007 \mathrm{~h}^{-1}$. Therefore, their potential cellular $\mathrm{N}$-turnover was more than one order of magnitude faster by $\mathrm{N}_{2}$-fixation than by ammonium assimilation. The low ammonium assimilation by filamentous $\mathrm{N}_{2}$-fixing 
cyanobacteria is also supported by the observation that cyanobacterial colonies release significant amounts of ammonium [7, 8] and DON [16, 18], depending on their energy reserves. Colony-forming cyanobacteria such as the Baltic Sea strains and the widespread Trichodesmium may indeed re-assimilate only parts of their newly released $\mathrm{N}$ [69] while the remaining parts may benefit attached microbiota and co-occurring plankton [20, 23, 25, 70].

\section{Single-cell ammonium assimilation by non- diazotrophs}

Single-cell ammonium and C-assimilation rates were highly variable, often differing by one order of magnitude among diverse taxa and even single species (Fig. 2). Such phenotypic heterogeneity in metabolism can result from (i) diffusion-limited nutrient assimilation in chain- or colonyforming species in which cells are exposed to distinct chemical microenvironments [44], (ii) variable substrate preferences of cells within the same population [71, 72] or (iii) metabolic versatility within cell populations to cope with substrate fluctuations [73].

Colony-forming picocyanobacteria and Pseudanabaena have been considered as potential $\mathrm{N}_{2}$-fixers $[74,75]$. However, recent SIMS-based analyses did not confirm substantial $\mathrm{N}_{2}$-fixation with rates as low as $0.001-0.004 \mathrm{~h}^{-1}$ of those taxa in the Baltic Sea [38]. Instead, they seem to preferably assimilate ammonium at rates of $0.006-0.029 \mathrm{~h}^{-1}$ (Table 2). Total ammonium assimilation was dominated by autotrophic picocyanobacteria and heterotrophic bacteria (Fig. 3b) which apparently competed for the same N-source. Their assimilation rates agreed well with recent studies on a single-cell level for both taxa [23] and on a community level for prokaryotes [76] and specifically heterotrophic bacteria [77, 78]. Single-cell assimilation rates of Synechococcus were also similar to those reported from the Pacific Ocean [72] and to doubling times of $\sim 1-2$ days (equivalent to net $\mathrm{N}$-assimilation rates of $0.021-0.042 \mathrm{~h}^{-1}$ ) measured for entire picocyanobacterial communities during summer in the Baltic $[79,80]$. Such fast assimilation rates may substantially support higher trophic levels, since picocyanobacteria are actively grazed by zooplankton in the Baltic Sea [81, 82]. Heterotrophic bacteria usually regenerate ammonium through the degradation of dissolved organic matter (DOM), i.e., ammonification. Still, their ammonium assimilation rates were high, comparable to those of phototrophic, non- $\mathrm{N}_{2}$-fixing cells (Fig. 2 and Table 2). Potentially, some cells received their ${ }^{15} \mathrm{~N}$ enrichment not directly from ${ }^{15} \mathrm{~N}$-ammonium assimilation but rather from ${ }^{15} \mathrm{~N}$-DON released after ${ }^{15} \mathrm{~N}$-assimilation by the bacterioplankton or phytoplankton. DON greatly supports plankton nutrition $[83,84]$ and its release accounts for on average $20-30 \%$ of the ammonium assimilation $[85,86]$.
However, only parts of the recently released DON may be bioavailable [87] and DON turnover times are rather long, in the order of days $[18,88,89]$. We thus consider the ${ }^{15} \mathrm{~N}$ enrichment in cells due to recently excreted ${ }^{15} \mathrm{~N}$-DON as minor during our 3-h incubations. In the Baltic Sea, the C:N ratios of DOM are $>10$ [90] while bacterial C:N ratios are commonly 3.7 [91] with mean bacterial growth efficiencies (BGE) of 0.34 [92]. Such combination of high BGE, high substrate $\mathrm{C}: \mathrm{N}$ ratio and low bacterial $\mathrm{C}: \mathrm{N}$ ratio implies net $\mathrm{N}$ assimilation rather than release by heterotrophic bacteria [93]. Regenerated ammonium can also derive from, e.g., zooplankton grazing, release by phytoplankton, viral infections or cell lysis [6]. Teasing these processes apart is challenging but should be targeted in future studies, to untangle the herein reported large fraction of ammonium regeneration of unknown sources (Fig. 3c).

\section{Nutrient acquisition in small vs. large cells}

Small cells are generally believed to grow faster than large cells at low steady-state nutrient concentrations because of their higher cell surface-to-volume ratios [94]. Nevertheless, we measured similar ammonium-assimilation and even $\mathrm{C}$-assimilation rates $\left(\mathrm{h}^{-1}\right)$ in small picocyanobacteria and large chain-forming diatoms (Table 2). Chaetoceros even showed $\mathrm{N}$-assimilation rates similar to those predicted by theoretical diffusion-limited ammonium supply. $\mathrm{N}$-assimilation rates of Chaetoceros based on ammonium during June $\left(0.034 \pm 0.016 \mathrm{~h}^{-1}\right)$ were also similar to those based on nitrate $\left(0.023 \pm 0.015 \mathrm{~h}^{-1}\right.$ at $\left.0.3 \mu \mathrm{M}\right)$ during diffusion-limited growth at the end of the spring bloom at the same sampling station [44]. Diatoms may thus compete well for dissolved inorganic $\mathrm{N}$ not only in upwelling, nitrate-rich areas but also in the N-poor regions. In fact, diatom diversity is comparable in oligotrophic and nutrientrich areas with Chaetoceros as the most abundant and diverse genus [95], and diatoms have been shown to compete well for $\mathrm{N}$ released from $\mathrm{N}_{2}$-fixation [20, 23]. A recent study has also demonstrated that Chaetoceros contributed $\geq 20 \%$ to the total $\mathrm{C}$ and $\mathrm{N}$ assimilation under $\mathrm{N}$-depleted conditions although it accounted for only $6 \%$ of the phytoplankton biomass [62]. However, high C-specific and $\mathrm{N}$-specific assimilation rates of Chaetoceros contradicted their low population biomass $\left(<0.2 \mu \mathrm{g} \mathrm{C} \mathrm{L}{ }^{-1}\right)$ in this study, which remains enigmatic at present. Assimilation rates measured by SIMS are a relative measure of the elemental turn-over within cells, independent on cell sizes. Those rates may reflect single-cell growth rates, yet they may not necessarily correlate to actual biomass built-up. Rates obtained from SIMS analyses assume that the CNbiomass is evenly distributed in cells, which may not always hold true. For instance, nutrient-storing vacuoles can cover large parts of the cell volume in diatoms but 
account for proportionally little biomass-a structural feature which may overestimate $\mathrm{N}$-growth rates of diatoms when using SIMS [96]. Moreover, the population size of Chaetoceros might have been limited by other nutrients than $\mathrm{N}$ and/or moderated by fast sinking as indicated by their proportionally high retrieval in sediment traps [97] and high grazing pressure from zooplankton [24].

In conclusion, our experimental conditions resembled growth conditions for plankton communities-including $\mathrm{N}$ depletion, ammonium regeneration and $\mathrm{N}_{2}$-fixation-that currently predominate in marine waters and may even intensify in the future [98-100]. Under these conditions, eukaryotic diatoms showed a fast C-turnover and N-turnover on a singlecell level but minor population biomass. In contrast, prokaryotic picoplankton of different trophic levels, i.e., heterotrophic bacteria and autotrophic picocyanobacteria quickly turned over their cellular C-content and $\mathrm{N}$-content by $\mathrm{C}$ fixation and ammonium assimilation, respectively, and also dominated the community biomass, thereby facilitating rapid nutrient dynamics in $\mathrm{N}$-depleted marine systems.

Acknowledgements This work was supported by FORMAS (2152009-813 to Ragnar Elmgren, H.P. and V.B., 215-2010-779 to H.P.), as well as by the BEAM Program (to H.P., I.K. and S.B.), Baltic Sea Centre at Stockholm University (Askö grant to I.K.), Swedish Research Council (VR 2017-03746 to H.P. and V.B.) and German Science Foundation (DFG-IV-124/3-1 to H.P. Grossart to support I. K.). We thank the staff at Askö Laboratory, Jakob Walve and Malin Olofsson for field assistance, Gaute Lavik and Hannah Marchant for help with MIMS-analyses, Lev Ilyinsky and Kerstin Lindén for assistance during SIMS analyses, Anna-Lea Golz and Helena Höglander for support during microscopy, Moritz Holtappels for discussing calculations on ammonium processes, the DEEP monitoring group for providing nutrient data and CTD profiles and the Max Planck Society for supporting the Mass Spectrometer Facilities at the MPI, Bremen. This is Nordsim contribution \#596. We also appreciate the helpful input from three anonymous reviewers.

Author contributions I.K. and H.P. designed the study and performed the experiments. I.K., S.B., M.J.W., S.L., D.T., M.M.M.K., V.B. and H.P. contributed to sample and data analyses. I.K., H.P, S.B. and V.B. wrote the manuscript with the help and approval from all other coauthors.

\section{Compliance with ethical standards}

Conflict of interest The authors declare that they have no conflict of interest.

Publisher's note: Springer Nature remains neutral with regard to jurisdictional claims in published maps and institutional affiliations.

Open Access This article is licensed under a Creative Commons Attribution 4.0 International License, which permits use, sharing, adaptation, distribution and reproduction in any medium or format, as long as you give appropriate credit to the original author(s) and the source, provide a link to the Creative Commons license, and indicate if changes were made. The images or other third party material in this article are included in the article's Creative Commons license, unless indicated otherwise in a credit line to the material. If material is not included in the article's Creative Commons license and your intended use is not permitted by statutory regulation or exceeds the permitted use, you will need to obtain permission directly from the copyright holder. To view a copy of this license, visit http://creativecommons. org/licenses/by/4.0/.

\section{References}

1. Karl D, Michaels A, Bergman B, Capone D, Carpenter E, Letelier R, et al. Dinitrogen fixation in the world's oceans. Biogeochemistry. 2002;57-58:47-98.

2. Harrison WG. Nutrient recycling in production experiments. ICES Mar. Sci. Symp. 1993;197:149-58.

3. Glibert PM. Primary production and pelagic nitrogen cycling. In: Blackburn TH, Soerensen J, editors. Nitrogen cycling in coastal marine environments. Chichester: John Wiley \& Son Ltd; 1988. p. 3-31.

4. Mulholland MR, Lomas MW. Chapter 7 - Nitrogen uptake and assimilation. In: Capone DG, Bronk DA, Mulholland MR, Carpenter EJ, editors. Nitrogen in the marine environment. 2nd edn. San Diego: Academic Press; 2008. p. 303-84.

5. Glibert PM, Wilkerson FP, Dugdale RC, Raven JA, Dupont CL, Leavitt PR, et al. Pluses and minuses of ammonium and nitrate uptake and assimilation by phytoplankton and implications for productivity and community composition, with emphasis on nitrogen-enriched conditions. Limnol Oceanogr. 2016;61: 165-97.

6. Bronk DA, Steinberg DK. Chapter 8-Nitrogen regeneration. In: Capone DG, Bronk DA, Mulholland MR, Carpenter EJ, editors. Nitrogen in the marine environment. 2nd Edn. San Diego: Academic Press; 2008. p. 385-467.

7. Ploug H, Adam B, Musat N, Kalvelage T, Lavik G, WolfGladrow D, et al. Carbon, nitrogen and $\mathrm{O}_{2}$ fluxes associated with the cyanobacterium Nodularia spumigena in the Baltic Sea. ISME J. 2011;5:1549-58.

8. Ploug H, Musat N, Adam B, Moraru CL, Lavik G, Vagner T, et al. Carbon and nitrogen fluxes associated with the cyanobacterium Aphanizomenon sp. in the Baltic Sea. ISME J. 2010;4:1215-23.

9. Berthelot H, Bonnet S, Camps M, Grosso O, Moutin T. Assessment of the dinitrogen released as ammonium and dissolved organic nitrogen by unicellular and filamentous marine diazotrophic cyanobacteria grown in culture. Front Mar Sci. 2015;2:80.

10. Glibert PM, Miller CA, Garside C, Roman MR, McManus GB. $\mathrm{NH}_{4}^{+}$regeneration and grazing: interdependent processes in size-fractionated ${ }^{15} \mathrm{NH}_{4}{ }^{+}$experiments. Mar Ecol Prog Ser. 1992;82:65-74.

11. Miller CA, Penry DL, Glibert PM. The impact of trophic interactions on rates of nitrogen regeneration and grazing in Chesapeake Bay. Limnol Oceanogr. 1995;40:1005-11.

12. Radajewski S, Ineson P, Parekh NR, Murrell JC. Stable-isotope probing as a tool in microbial ecology. Nature. 2000;403:646-9.

13. Fawcett SE, Lomas MW, Casey JR, Ward BB, Sigman DM. Assimilation of upwelled nitrate by small eukaryotes in the Sargasso Sea. Nat Geosci. 2011;4:717-22.

14. Musat N, Foster R, Vagner T, Adam B, Kuypers MMM. Detecting metabolic activities in single cells, with emphasis on nanoSIMS. FEMS Microbiol Rev. 2012;36:486-11.

15. Berthelot H, Moutin T, L’Helguen S, Leblanc K, Hélias S, Grosso $\mathrm{O}$, et al. Dinitrogen fixation and dissolved organic nitrogen fueled primary production and particulate export during the VAHINE mesocosm experiment (New Caledonia lagoon). Biogeosciences. 2015;12:4099-112. 
16. Wannicke N, Koch BP, Voss M. Release of fixed $\mathrm{N}_{2}$ and $\mathrm{C}$ as dissolved compounds by Trichodesmium erythreum and Nodularia spumigena under the influence of high light and high nutrient (P). Aquat Microb Ecol. 2009;57:175-89.

17. Glibert PM, Bronk DA. Release of dissolved organic nitrogen by marine diazotrophic cyanobacteria, Trichodesmium spp. Appl Environ Microbiol. 1994;60:3996-4000.

18. Loick-Wilde N, Weber SC, Eglite E, Liskow I, Schulz-Bull D, Wasmund N, et al. De novo amino acid synthesis and turnover during $\mathrm{N}_{2}$ fixation. Limnol Oceanogr. 2018;63:1076-92.

19. Caffin M, Berthelot H, Cornet-Barthaux V, Barani A, Bonnet S. Transfer of diazotroph-derived nitrogen to the planktonic food web across gradients of $\mathrm{N}_{2}$ fixation activity and diversity in the western tropical South Pacific Ocean. Biogeosciences. 2018;15:3795-810.

20. Bonnet S, Berthelot H, Turk-Kubo K, Cornet-Barthaux V, Fawcett S, Berman-Frank I, et al. Diazotroph derived nitrogen supports diatom growth in the South West Pacific: a quantitative study using nanoSIMS. Limnol Oceanogr. 2016;61:1549-62.

21. Mulholland MR, Bernhardt PW, Ozmon I, Procise LA, Garrett M, O'Neil JM, et al. Contribution of diazotrophy to nitrogen inputs supporting Karenia brevis blooms in the Gulf of Mexico. Harmful Algae. 2014;38:20-29.

22. Garcia N, Raimbault P, Sandroni V. Seasonal nitrogen fixation and primary production in the Southwest Pacific: nanoplankton diazotrophy and transfer of nitrogen to picoplankton organisms. Mar Ecol Prog Ser. 2007;343:25-33.

23. Adam B, Klawonn I, Svedén JB, Bergkvist J, Nahar N, Walve J, et al. $\mathrm{N}_{2}$-fixation, ammonium release and $\mathrm{N}$-transfer to the microbial and classical food web within a plankton community. ISME J. 2016;10:450-9.

24. Karlson AML, Duberg J, Motwani NH, Hogfors H, Klawonn I, Ploug $\mathrm{H}$, et al. Nitrogen fixation by cyanobacteria stimulates production in Baltic food webs. Ambio. 2015;44:413-26.

25. Wannicke N, Korth F, Liskow I, Voss M. Incorporation of diazotrophic fixed $\mathrm{N}_{2}$ by mesozooplankton-Case studies in the southern Baltic Sea. J Mar Syst. 2013;117-118:1-13.

26. Eglite E, Wodarg D, Dutz J, Wasmund N, Nausch G, Liskow I, et al. Strategies of amino acid supply in mesozooplankton during cyanobacteria blooms: a stable nitrogen isotope approach. Ecosphere. 2018;9:e02135.

27. Raimbault P, Garcia N. Evidence for efficient regenerated production and dinitrogen fixation in nitrogen-deficient waters of the South Pacific Ocean: impact on new and export production estimates. Biogeosciences. 2008;5:323-38.

28. Savchuk OP. Large-scale nutrient dynamics in the Baltic Sea, 1970-2016. Front Mar Sci. 2018;5:95.

29. Larsson U, Hajdu S, Walve J, Elmgren R. Baltic Sea nitrogen fixation estimated from the summer increase in upper mixed layer total nitrogen. Limnol Oceanogr. 2001;46:811-20.

30. Rolff C, Almesjö L, Elmgren R. Nitrogen fixation and abundance of the diazotrophic cyanobacterium Aphanizomenon sp. in the Baltic Proper. Mar Ecol Prog Ser. 2007;332:107-18.

31. Svedén JB, Walve J, Larsson U, Elmgren R. The bloom of nitrogen-fixing cyanobacteria in the northern Baltic Proper stimulates summer production. J Mar Syst. 2016;163:102-12.

32. Klawonn I, Lavik G, Böning P, Marchant HK, Dekaezemacker J, Mohr W, et al. Simple approach for the preparation of ${ }^{15-15} \mathrm{~N}_{2}-$ enriched water for nitrogen fixation assessments: evaluation, application and recommendations. Front Microbiol. 2015;6: 769.

33. Dabundo R, Lehmann MF, Treibergs L, Tobias CR, Altabet MA, Moisander PH, et al. The contamination of commercial ${ }^{15} \mathrm{~N}_{2}$ gas stocks with ${ }^{15} \mathrm{~N}$-labeled nitrate and ammonium and consequences for nitrogen fixation measurements. PLoS ONE. 2014;9: e110335.
34. Holmes RM, Aminot A, Kérouel R, Hooker BA, Peterson BJ. A simple and precise method for measuring ammonium in marine and freshwater ecosystems. Can J Fish Aquat Sci. 1999;56:1801-8.

35. Warembourg FR. Nitrogen fixation in soil and plant systems. In: Blackburn RKH, editor. Nitrogen Isotope Techniques. San Diego: Academic Press; 1993. p. 127-56.

36. Füssel J, Lam P, Lavik G, Jensen MM, Holtappels M, Günter M, et al. Nitrite oxidation in the Namibian oxygen minimum zone. ISME J. 2012;6:1200-09.

37. Bonaglia S, Deutsch B, Bartoli M, Marchant HK, Brüchert V. Seasonal oxygen, nitrogen and phosphorus benthic cycling along an impacted Baltic Sea estuary: Regulation and spatial patterns. Biogeochemistry. 2014;119:139-60.

38. Klawonn I, Nahar N, Walve J, Andersson B, Olofsson M, Svedén JB, et al. Cell-specific nitrogen- and carbon-fixation of cyanobacteria in a temperate marine system (Baltic Sea). Environ Microbiol. 2016;18:4596-609.

39. Rees AP, Joint I, Donald KM. Early spring bloom phytoplankton-nutrient dynamics at the Celtic Sea Shelf Edge. Deep-Sea Res Pt I. 1999;46:483-510.

40. Sahlsten E. Nitrogenous nutrition in the euphotic zone of the Central North Pacific Gyre. Mar Biol. 1987;96:433-9.

41. Harrison WG, Harris LR, Irwin BD. The kinetics of nitrogen utilization in the oceanic mixed layer: Nitrate and ammonium interactions at nanomolar concentrations. Limnol Oceanogr. 1996;41:16-32.

42. Polerecky L, Adam B, Milucka J, Musat N, Vagner T, Kuypers MMM. Look@NanoSIMS- a tool for the analysis of nanoSIMS data in environmental microbiology. Environ Microbiol. 2012;14:1009-23.

43. Svedén JB, Adam B, Walve J, Nahar N, Musat N, Lavik G, et al. High cell-specific rates of nitrogen and carbon fixation by the cyanobacterium Aphanizomenon sp. at low temperatures in the Baltic Sea. FEMS Microbiol Ecol. 2015;91:pii: fiv131.

44. Bergkvist J, Klawonn I, Whitehouse MJ, Lavik G, Brüchert V, Ploug $\mathrm{H}$. Turbulence simultaneously stimulates small- and largescale $\mathrm{CO}_{2}$ sequestration by chain-forming diatoms in the sea. Nat Commun. 2018;9:3046.

45. HELCOM. Manual for Marine Monitoring in the COMBINE Programme of HELCOM. http://www.helcom.fi/action-areas/ monitoring-and-assessment/manuals-and-guidelines/combine-ma nual (2017).

46. Sherwood TK, Pigford RL, Wilke CR. Mass transfer. New York, USA: McGraw-Hill Book Company; 1975.

47. Clift R, Grace JR, Weber ME. Bubbles, drops, and particles. New York, London: Academic Press; 1978. p. 380.

48. Mulholland MR, Bronk DA, Capone DG. Dinitrogen fixation and release of ammonium and dissolved organic nitrogen by Trichodesmium IMS101. Aquat Microb Ecol. 2004; 37:85-94.

49. Sörensen F, Sahlsten E. Nitrogen dynamics of a cyanobacteria bloom in the Baltic Sea: new versus regenerated production. Mar Ecol Prog Ser. 1987;37:277-84.

50. Harrison WG, Douglas D, Falkowski P, Rowe G, Vidal J. Summer nutrient dynamics of the Middle Atlantic Bight: nitrogen uptake and regeneration. J Plankton Res. 1983;5:539-56.

51. Suttle CA, Fuhrman JA, Capone DG. Rapid ammonium cycling and concentration- dependent partitioning of ammonium and phosphate: Implications for carbon transfer in planktonic communities. Limnol Oceanogr. 1990;35:424-33.

52. Harrison WG. Experimental measurements of nitrogen remineralization in coastal waters 1. Limnol Oceanogr. 1978;23:684-94.

53. Brezonik PL. Nitrogen: Sources and transformations in natural waters. In: Allen HE, Kramer JR, editors. Nutrients in natural waters. New York: Wiley-Interscience Publications; 1972. p. 1-50. 
54. Kanda J, Ziemann DA, Conquest LD, Bienfang PK. Nitrate and ammonium uptake by phytoplankton populations during the spring bloom in Auke Bay, Alaska. Estuar Coast Shelf Sci. 1990;30:509-24.

55. Heiskanen AS, Kononen K. Sedimentation of vernal and late summer phytoplankton communities in the coastal Baltic Sea. Arch fur Hydrobiol. 1994;131:175-98.

56. Berg GM, Glibert PM, Jørgensen NOG, Balode M, Purina I. Variability in inorganic and organic nitrogen uptake associated with riverine nutrient input in the Gulf of Riga, Baltic Sea. Estuaries. 2001;24:204-14.

57. Dugdale RC, Goering JJ. Uptake of new and regenerated forms of nitrogen in primary productivity. Limnol Oceanogr. 1967;12:196-206.

58. Musat N, Halm H, Winterholler B, Hoppe P, Peduzzi S, Hillion $\mathrm{F}$, et al. A single-cell view on the ecophysiology of anaerobic phototrophic bacteria. Proc Natl Acad Sci USA. 2008;105:17861-6.

59. Morono Y, Terada T, Nishizawa M, Ito M, Hillion F, Takahata $\mathrm{N}$, et al. Carbon and nitrogen assimilation in deep subseafloor microbial cells. Proc Natl Acad Sci USA. 2011;108:18295-300.

60. Pernice M, Meibom A, Van Den Heuvel A, Kopp C, DomartCoulon I, Hoegh-Guldberg O, et al. A single-cell view of ammonium assimilation in coral-dinoflagellate symbiosis. ISME J. 2012;6:1314-24.

61. Bombar D, Paerl RW, Anderson R, Riemann L. Filtration via conventional glass fiber filters in ${ }^{15} \mathrm{~N}_{2}$ tracer assays fails to capture all nitrogen-fixing prokaryotes. Front Mar Sci. 2018;5:6.

62. Olofsson M, Robertson ER, Edler L, Arneborg L, Whitehouse M, Ploug H. Nitrate and ammonium fluxes to diatoms and dinoflagellates at a single cell level in mixed field communities in the sea. Sci Rep. 2019;9:1424.

63. Rönner U. Nitrogen transformations in the Baltic proper: denitrification counteracts eutrophication. Ambio. 1985;14:134-8.

64. Klawonn I, Bonaglia S, Brüchert V, Ploug H. Aerobic and anaerobic nitrogen transformation processes in $\mathrm{N}_{2}$-fixing cyanobacterial aggregates. ISME J. 2015;9:1456-66.

65. Wan XS, Sheng H-X, Dai M, Zhang Y, Shi D, Trull TW, et al. Ambient nitrate switches the ammonium consumption pathway in the euphotic ocean. Nat Commun. 2018;9:915.

66. Happel E, Bartl I, Voss M, Riemann L. Extensive nitrification and active ammonia oxidizers in two contrasting coastal systems of the Baltic Sea. Environ Microbiol. 2018;20:2913-26.

67. Bartl I, Liskow I, Schulz K, Umlauf L, Voss M. River plume and bottom boundary layer - Hotspots for nitrification in a coastal bay? Estuar Coast Shelf Sci. 2018;208:70-82.

68. Zakrisson A, Larsson U, Höglander H. Do Baltic Sea diazotrophic cyanobacteria take up combined nitrogen in situ? J Plankton Res. 2014;36:1368-80.

69. Mulholland MR, Capone DG. The nitrogen physiology of the marine $\mathrm{N}_{2}$-fixing cyanobacteria Trichodesmium spp. Trends Plant Sci. 2000;5:148-53.

70. Eichner MJ, Klawonn I, Wilson ST, Littmann S, Whitehouse MJ, Church MJ, et al. Chemical microenvironments and singlecell carbon and nitrogen uptake in field-collected colonies of Trichodesmium under different $\mathrm{pCO}_{2}$. ISME J. 2017;11: 1305-17.

71. Matantseva O, Skarlato S, Vogts A, Pozdnyakov I, Liskow I, Schubert H, et al. Superposition of individual activities: Ureamediated suppression of nitrate uptake in the dinoflagellate Prorocentrum minimum revealed at the population and singlecell levels. Front Microbiol. 2016;7:1310.

72. Berthelot H, Duhamel S, L'Helguen S, Maguer J-F, Wang S, Cetinić I, et al. NanoSIMS single cell analyses reveal the contrasting nitrogen sources for small phytoplankton. ISME J. 2018;13:651-62.
73. Schreiber F, Littmann S, Lavik G, Escrig S, Meibom A, Kuypers MMM, et al. Phenotypic heterogeneity driven by nutrient limitation promotes growth in fluctuating environments. Nat Microbiol. 2016;1:16055.

74. Farnelid H, Öberg T, Riemann L. Identity and dynamics of putative $\mathrm{N}_{2}$-fixing picoplankton in the Baltic Sea proper suggest complex patterns of regulation. Environ Microbiol Rep. 2009;1:145-54.

75. Wasmund N, Voss M, Lochte K. Evidence of nitrogen fixation by non-heterocystous cyanobacteria in the Baltic Sea and recalculation of a budget of nitrogen fixation. Mar Ecol Prog Ser. 2001;214:1-14.

76. Wheeler PA, Kirchman DL. Utilization of inorganic and organic nitrogen by bacteria in marine systems. Limnol Oceanogr. 1986;31:998-1009.

77. Kirchman DL. The uptake of inorganic nutrients by heterotrophic bacteria. Microb Ecol. 1994;28:255-71.

78. Allen AE, Howard-Jones MH, Booth MG, Frischer ME, Verity PG, Bronk DA, et al. Importance of heterotrophic bacterial assimilation of ammonium and nitrate in the Barents Sea during summer. J Mar Syst. 2002;38:93-108.

79. Kuosa H. Picoplanktonic algae in the northern Baltic Sea: seasonal dynamics and flagellate grazing. Mar Ecol Prog Ser. 1991;73:269-76.

80. Stal LJ, Albertano P, Bergman B, Von Bröckel K, Gallon JR, Hayes PK, et al. BASIC: Baltic Sea cyanobacteria. An investigation of the structure and dynamics of water blooms of cyanobacteria in the Baltic Sea - Responses to a changing environment. Cont Shelf Res. 2003;23:1695-714.

81. Loick-Wilde N, Fernández-Urruzola I, Eglite E, Liskow I, Nausch M, Schulz-Bull D, et al. Stratification, nitrogen fixation, and cyanobacterial bloom stage regulate the planktonic food web structure. Glob Change Biol. 2019;25:794-810.

82. Motwani NH, Duberg J, Svedén JB, Gorokhova E. Grazing on cyanobacteria and transfer of diazotrophic nitrogen to zooplankton in the Baltic Sea. Limnol Oceanogr. 2018;63:672-86.

83. Korth F, Deutsch B, Liskow I, Voss M. Uptake of dissolved organic nitrogen by size-fractionated plankton along a salinity gradient from the North Sea to the Baltic Sea. Biogeochemistry. 2012;111:347-60.

84. Bronk DA, See JH, Bradley P, Killberg L. DON as a source of bioavailable nitrogen for phytoplankton. Biogeosciences. 2007;4:283-96.

85. Bronk DA, Ward BB. Magnitude of dissolved organic nitrogen release relative to gross nitrogen uptake in marine systems. Limnol Oceanogr. 2000;45:1879-83.

86. Bronk DA, Glibert PM, Malone TC, Banahan S, Sahlsten E. Inorganic and organic nitrogen cycling in Chesapeake Bay: Autotrophic versus heterotrophic processes and relationships to carbon flux. Aquat Microb Ecol. 1998;15:177-89.

87. Sipler RE, Bronk DA, Seitzinger SP, Lauck RJ, McGuinness LR, Kirkpatrick GJ, et al. Trichodesmium-derived dissolved organic matter is a source of nitrogen capable of supporting the growth of toxic red tide Karenia brevis. Mar Ecol Prog Ser. 2013;483:3145 .

88. Bronk DA, Glibert PM, Ward BB. Nitrogen uptake, dissolved organic nitrogen release, and new production. Science. 1994;265:1843-6.

89. Berman T, Bronk DA. Dissolved organic nitrogen: a dynamic participant in aquatic ecosystems. Aquat Microb Ecol. 2003;31:279-305.

90. Kuparinen J, Heinänen A. Inorganic nutrient and carbon controlled bacterioplankton growth in the Baltic Sea. Estuar Coast Shelf Sci. 1993;37:271-85.

91. Lee S, Fuhrman JA. Relationships between biovolume and biomass of naturally derived marine bacterioplankton. Appl Environ Microbiol. 1987;53:1298-303. 
92. Del Giorgio PA, Cole JJ. Bacterial growth efficiency in natural aquatic systems. Annu Rev Ecol Syst. 1998;29:503-41.

93. Goldman JC, Caron DA, Dennett MR. Regulation of gross growth efficiency and ammonium regeneration in bacteria by substrate C: N ratio. Limnol Oceanogr. 1987;32:1239-52.

94. Banse K. Rates of growth, respiration and photosynthesis of unicellular algae as related to cell size-a review. J Phycol. 1976;12:135-40.

95. Malviya S, Scalco E, Audic S, Vincent F, Veluchamy A, Poulain $\mathrm{J}$, et al. Insights into global diatom distribution and diversity in the world's ocean. Proc Natl Acad Sci USA. 2016; 113:1516-25.

96. Olofsson M, Kourtchenko O, Zetsche E-M, Marchant HK, Whitehouse MJ, Godhe A, et al. High single-cell diversity in carbon and nitrogen assimilations by a chain-forming diatom across a century. Environ Microbiol. 2018;0:142-51.
97. Tallberg P, Heiskanen AS. Species-specific phytoplankton sedimentation in relation to primary production along an inshoreoffshore gradient in the Baltic sea. J Plankton Res. 1998;20:2053-70.

98. Beman JM, Chow CE, King AL, Feng Y, Fuhrman JA, Andersson A, et al. Global declines in oceanic nitrification rates as a consequence of ocean acidification. Proc Natl Acad Sci USA. 2011;108:208-13.

99. Berman-Frank I, Chen Y-B, Gao Y, Fennel K, Follows MJ, Milligan AJ, et al. Chapter 35-Feedbacks between the nitrogen, carbon and oxygen cycles. Nitrogen in the marine environment. 2nd edn. San Diego: Academic Press; 2008. p. $1537-63$.

100. Hutchins DA, Fu F. Microorganisms and ocean global change. Nat Microbiol. 2017;2:17058. 